\title{
WATER TARIFF SETTING AND ITS WELFARE IMPLICATIONS: EVIDENCE FROM CITIES IN THE PEOPLE'S REPUBLIC OF CHINA
}

Yi Jiang, Renz Adrian T. Calub, and Xiaoting Zheng

NO. 580

May 2019
ADB ECONOMICS WORKING PAPER SERIES 


\section{Water Tariff Setting and Its Welfare Implications: Evidence from Cities in the People's Republic of China}

Yi Jiang, Renz Adrian T. Calub, and Xiaoting Zheng

No. 580 | May 2019
Yi Jiang (yijiang@adb.org) is a senior economist and Renz Adrian T. Calub (rcalub.consultant@adb.org) is a consultant in the Economic Research and Regional Cooperation Department, Asian Development Bank (ADB). Xiaoting Zheng (zheng_xiaoting@hotmail.com) is an associate professor in the Department of Economics, Jinan University.

The authors are grateful to Yasuyuki Sawada and Rana Hasan for constructive comments. The seminar participants at ADB and Jinan University also provided very useful suggestions. Xiaoting Zheng thanks the National Natural Science Foundation of China (Project No. 71603100) for financial support. 
(C) 2019 Asian Development Bank 6 ADB Avenue, Mandaluyong City, 1550 Metro Manila, Philippines

Tel +632632 4444; Fax +6326362444

www.adb.org

Some rights reserved. Published in 2019.

ISSN 2313-6537 (print), 2313-6545 (electronic)

Publication Stock No. WPS190159-2

DOI: http://dx.doi.org/10.22617/WPS190159-2

The views expressed in this publication are those of the authors and do not necessarily reflect the views and policies of the Asian Development Bank (ADB) or its Board of Governors or the governments they represent.

ADB does not guarantee the accuracy of the data included in this publication and accepts no responsibility for any consequence of their use. The mention of specific companies or products of manufacturers does not imply that they are endorsed or recommended by ADB in preference to others of a similar nature that are not mentioned.

By making any designation of or reference to a particular territory or geographic area, or by using the term "country" in this document, $A D B$ does not intend to make any judgments as to the legal or other status of any territory or area.

This work is available under the Creative Commons Attribution 3.0 IGO license (CC BY 3.0 IGO)

https://creativecommons.org/licenses/by/3.o/igo/. By using the content of this publication, you agree to be bound by the terms of this license. For attribution, translations, adaptations, and permissions, please read the provisions and terms of use at https://www.adb.org/terms-use\#openaccess.

This CC license does not apply to non-ADB copyright materials in this publication. If the material is attributed to another source, please contact the copyright owner or publisher of that source for permission to reproduce it. $\mathrm{ADB}$ cannot be held liable for any claims that arise as a result of your use of the material.

Please contact pubsmarketing@adb.org if you have questions or comments with respect to content, or if you wish to obtain copyright permission for your intended use that does not fall within these terms, or for permission to use the ADB logo.

Corrigenda to ADB publications may be found at http://www.adb.org/publications/corrigenda.

Notes:

In this publication, “\$” refers to United States dollars.

ADB recognizes "China" as the People's Republic of China.

The ADB Economics Working Paper Series presents data, information, and/or findings from ongoing research and studies to encourage exchange of ideas and to elicit comment and feedback about development issues in Asia and the Pacific. Since papers in this series are intended for quick and easy dissemination, the content may or may not be fully edited and may later be modified for final publication. 


\section{CONTENTS}

TABLES AND FIGURES

ABSTRACT

$\begin{array}{lll}\text { I. INTRODUCTION } & 1\end{array}$

$\begin{array}{lll}\text { II. DATA } & 3\end{array}$

III. $\quad$ URBAN WATER TARIFF SETTING

A. Empirical Model $\quad 9$

B. Results 10

IV. WATER DEMAND ESTIMATION

A. Empirical Model $\quad 14$

$\begin{array}{ll}\text { B. Results } & 15\end{array}$

$\begin{array}{ll}\text { V. WATER SUPPLY ESTIMATION } & 20\end{array}$

VI. WELFARE ANALYSIS $\quad 24$

A. Price-Marginal Cost Gap and Deadweight Loss Under First-Best Pricing 24

B. Optimal Pricing with Nonrevenue Water 26

$\begin{array}{ll}\text { VII. CONCLUSION } & 28\end{array}$

$\begin{array}{ll}\text { REFERENCES } & 31\end{array}$ 


\section{TABLES AND FIGURES}

\section{TABLES}

$1 \quad$ Summary Statistics of Utility and City Characteristics 5

2 Summary Statistics of Water Tariffs 6

3 Average Weighted Tariffs versus Average Costs 8

4A Residential Water Tariff Regressions 12

4B Industrial Water Tariff Regressions 13

$5 \quad$ Water Demand Regressions-Ordinary Least Squares Estimation 17

6 Water Demand Regressions-Two-Stage Least Squares Estimation 19

$7 \quad$ Water Supply Cost Regression 21

8 Tariff-Marginal Cost Gaps and Deadweight Loss under First-Best Pricing 25

$9 \quad$ Illustration of Welfare Computations with Nonrevenue Water Considered 27

\section{FIGURES}

1 Time Trends for Nominal and Real Water Tariffs, 2000-2012 7

2 Estimated Marginal Cost Curves 


\begin{abstract}
We develop a framework to analyze urban water tariff setting and its welfare implications and apply it to a panel of cities in the People's Republic of China in the 2000s. First, we find that peer cities' water tariff levels have a significant influence on a city's choice of tariffs. We use the peer cities' average tariff as an instrumental variable to estimate water demand functions, which yields elasticity estimates of around 0.41 for both residential and industrial sectors. Second, estimation of cost functions reveals the supply of urban water services to be characterized by strong economies of scale with the majority of sample cityyears on the downward sloping segment of marginal cost curves. More than half of the sample have residential water tariffs higher than the corresponding marginal costs while the share increases to $71 \%$ for the industrial sector. The deadweight loss calculated under first-best pricing suggests moderate welfare loss due to prices deviating from the equilibrium. Finally, we show that taking into account nonrevenue water losses justifies an efficient price higher than the equilibrium price.
\end{abstract}

Keywords: deadweight loss, multiproduct cost function, nonrevenue water, water demand, water tariff

JEL codes: L95, Q21, Q25, Q28 


\section{INTRODUCTION}

Rapid urbanization is a feature of economic development in many developing countries. Managing urbanization well requires not only enormous investment in urban infrastructure, such as roads, water supply network, and waste water treatment facilities, but also calls for sound management of natural resources and the environment. One key resource is water, especially in countries such as the People's Republic of China (PRC) and India where water is scarce and agricultural production still consumes a large share of the stock (Jiang and Huang 2015). Setting tariffs properly to balance demands from different types of users and achieve water conservation is desirable and important.

The PRC's urbanization rate increased from $17.9 \%$ in 1978 to $58.5 \%$ in 2017. To support this fast growth, the central and local governments have built up infrastructure in urban areas. For instance, the PRC had a stock of 382,000 kilometers $(\mathrm{kms})$ of roads and $757,000 \mathrm{kms}$ of water supply pipes in urban areas by 2016, up from 160,000 kms and 255,000 kms in 2000, respectively (National Bureau of Statistics 2017, 2001). These statistics suggest that a city's water supply pipes are usually much longer than its roads. Thus, building or expanding the water supply system accounts for a large share of total urban infrastructure investment. Besides domestic sources of funding, which include regular fiscal budget and revenues from government bonds or land sale, developing countries have increasingly relied on external funding sources such as bilateral and multilateral donors and private investors to finance expansion of their urban water systems (Galiani, Gertler, and Schargrodsky 2005; Jiang and Zheng 2014). ${ }^{2}$

When these external investors participate in developing the water supply market, they pay considerable attention to water tariffs. To ensure that the projects they support are financially sustainable and improves water use efficiency, donors often ask local governments to raise water tariffs. Private investors also prefer higher water tariffs, which largely determine the return on their investment.

However, as in many other developing countries, proposals to increase water tariffs often meet resistance from the government and the public in the PRC. According to the Price Law of the PRC, water tariffs should be set by the government and public hearings must be convened in the process of setting new tariffs. ${ }^{3}$ It seems understandable that the public do not favor water tariff increase in general, given that water is essential to life and the operation of many water utilities lacks transparency. In the presence of pervasive negative feedback from the public, the local government tends to reject or postpone increases in water tariffs, or even turn down a proposal before a public hearing if negative feedback is expected.

While there is a debate on the urbanization rate of the PRC, since many city dwellers do not have residency status (hukou) and thus have no access to public services such as primary education in the cities, these people do contribute to the demand for urban water services.

2 For example, urban water supply accounts for about $20 \%$ of the World Bank's portfolio. http://www.worldbank.org/en/topic/watersupply\#2.

3 Article 18 of the 1997 Price Law of the PRC states that the government shall issue government-set or guided prices for merchandise and services if they are (i) of great importance to economic development and people's livelihood, (ii) resources in short supply, (iii) monopolized in supply in nature, (iv) important public utilities, and/or (v) important services of public welfare in nature. Article 23 states that public hearings should be organized by the price bureau of the government to solicit views from consumers, business operators, and other quarters to explore the necessity and feasibility of a price adjustment. 
There could be several reasons for the tendency of local governments to weigh the public's views more than the interest of the water utilities and their investors. First, water tariffs influence almost everyone relying on public water supply. An increase in water tariff against the public may backfire and cause difficulties for decision makers. Second, the revenue deficit due to sluggish water tariffs is unlikely to account for a large portion of a local government's budget. The government could subsidize the utility to cover the gap without engaging the public in an intense discussion. Finally, the government-as the supervisor and regulator of water utilities-may have better information on the actual (marginal) cost and profitability of water services than an external observer. In this case, it could be economically efficient for the government to reject or slow the pace of water tariff increase.

To assess whether the prevailing water tariffs are set properly, it is necessary to understand the key driving factors in the setting of water tariffs and measure the welfare consequence based on the supply and demand of water services. In this study, we develop a framework to empirically analyze these issues and apply it to a comprehensive panel dataset containing information on the quantity of water supply, consumption, and tariffs for over 200 cities in the PRC in the 2000 s. We begin with an examination of the evolution of urban water tariffs over time for both residential and industrial sectors. Next, we investigate how city-level factors including population, climate, economic characteristics, and peer cities' tariffs affect a city's residential and industrial water tariff levels, in both nominal and real terms. Third, we estimate water demand functions for residential and industrial users tackling the endogeneity of water tariffs with instrumental variables (IVs). We also estimate a translog cost function of water supply, whereby marginal cost functions are derived for residential and industrial sectors. Combining estimated water demand and marginal cost functions, we measure the potential welfare losses due to deviations of water tariffs from equilibrium levels. Finally, we discuss efficient pricing when the phenomenon of nonrevenue water is considered. ${ }^{4}$

Below, we highlight some findings that we consider relevant and novel in the literature. First, in panel model specifications controlling for city fixed effects and year fixed effects or provincial time trends, a city's water tariff level is highly correlated with its peer cities' average water tariff, where peer cities are those neighboring cities from the same province. This holds true for both residential and industrial water tariffs.

In the public economics literature, there is a strand of studies regarding strategic interactions in fiscal policies, and environmental and labor regulations among national or subnational governments. For instance, recent empirical studies document strong spatial correlations in tax rates for local property tax and income tax within countries (Lyytikäinen 2012, Edmark and Ågren 2008, Allers and Elhorst 2005), in the stringency of environmental policies among states of the United States (US) (Fredriksson and Millimet 2002), and in labor standards setting and enforcement across countries (Davies and Vadlamannati 2013). In the context of the PRC, there is evidence that city-level governments are engaged in strategic interactions with respect to undertaking investment to boost the economy (Yu, Zhou, and Zhu 2016) and safety regulations on coal mining (Shi and Xi 2018). Our finding extends this literature to the interactions among local governments in managing water resources.

Building on this result, we use peer cities' average tariff as an IV to estimate water demand functions. A naive ordinary least squares (OLS) estimation shows that price elasticity of water demand

4 Nonrevenue water can refer to both technical leakages as well as water consumed without payment made to the supplier. In this paper, we define nonrevenue water as system leakages into nature. We do not include water consumed by people who do not pay for it. 
is economically and statistically insignificant, and even positive in some cases. This may be because water tariffs are set endogenously. For example, the government of a growing city may adopt a higher tariff to rein in increasing demand for water. With a constant elasticity specification, the IV estimation implies that the price elasticity of water demand is around -0.41 for both residential and industrial use, which is statistically significant for the former. These estimates fall in the range of estimated elasticities found in the literature (see surveys in Dalhuisen et al. 2003, Worthington and Hoffman 2008, Nauges and Whittington 2009), and confirm the endogeneity of water tariff setting.

By estimating a translog multiproduct cost function, we show that urban water supply is clearly characterized by both economies of scale and scope. The marginal cost curves are inverted- $U$ shaped with majority of sample city-years on the downward sloping part of the curves. Overlaying the demand and supply functions, we find that more than half of the sample city-years have residential water tariffs higher than the corresponding marginal costs while the share increases to $71 \%$ for the industrial sector. This result counters the conventional wisdom that water tariffs are generally set too low in the PRC. ${ }^{5}$ Our estimation of deadweight loss under the first-best pricing rule suggests that the social welfare loss due to water tariffs deviating from the equilibrium price is moderate.

Finally, we consider efficient pricing with nonrevenue water, which accounts for $20 \%$ of total water supply on average. To the extent that nonrevenue water increases with water consumption and represents net social loss, a price higher than the equilibrium price can improve social welfare by encouraging water conservation and reducing nonrevenue water.

The rest of the paper is organized as follows. Section II describes the dataset used for our analysis. Section III discusses the institutional background and empirical analysis regarding urban water tariff setting. Sections IV and V estimate water demand and supply functions, respectively. Section VI estimates welfare loss under first-best pricing and discusses efficient pricing in the presence of nonrevenue water, and section VII concludes.

\section{DATA}

The data used for this study is a combination of several city-level datasets covering more than 200 prefecture-level cities from 2000 to 2012 . $^{6}$ First, we digitized the Annual Statistics of Urban Water Supply from 2000 to 2007, in which the reporting utilities provide detailed information on their water supply services, including total water supplied, water sold disaggregated by user sectors, total and groundwater supply capacity, cost per ton of water supplied, number of employees, total wage bill, length of water intake and supply pipes, number of meters, as well as water tariffs for different sectors.

The post-2006 tariff data are collected from the China Water Net, which publicizes monthly city water tariffs. ${ }^{7}$ We validated the data by checking available government documents regarding water tariff adjustments. The annual tariffs are the simple average of the monthly tariffs, in case the tariffs changed within the year.

5 See articles at https://www.economist.com/asia/2010/01/07/bottling-it and https://piie.com/blogs/china-economicwatch/economics-h2o-water-price-reforms-china, for example.

6 The number of cities varies slightly across the analyses due to missing data issue, while different variables are used in different regressions.

7 See www.h2o-china.com/price/. 
We obtained city-level characteristics such as population, area, gross domestic product (GDP) and its sectoral composition, and fiscal performance from the Chinese City Statistical Yearbooks. As the second subnational administrative level immediately below province, a prefecture is often referred to as a city in the PRC. It actually comprises an urban center and suburban or rural areas surrounding the center. The yearbooks contain separate statistics for the urban center as well as for the whole prefecture. Because water tariffs set by the prefecture government primarily relate to urban utilities supplying water to the urban centers, we used data of the urban center in the yearbooks in our analysis. ${ }^{8}$

We obtained yearly weather data from the China Meteorological Data Service Center. ${ }^{9}$ The dataset contains weather measurements collected by about 840 weather stations distributed across the country. We mapped them to the cities where the stations are located and took the average of rainfall and the maximum (minimum) of the yearly maximum (minimum) temperature across stations if multiple stations are found in the same city. Finally, to obtain a precise measure of water tariffs in real terms, we meticulously collected city-level consumer price index from provincial Statistical Yearbooks. Real tariffs are computed in yuan (CNY) with the base year 2000.

Table 1 presents the summary statistics of the above variables, except water tariffs. Data reported by water utilities are available from 2000 to 2007 (some variables are missing for 2000), while other city-level data are available from 2000 to 2011 or 2012. Averaged across cities and years, total annual water supply is 83.8 million cubic meters and water sold is 66.4 million cubic meters. The ratio of the two amounting to $79.2 \%$ could be considered as the approximate rate of revenue water. Residential users account for nearly half of the total water sold, while industrial users account for about $28 \%$. Other sectors including commercial, administrative, and special users consume less than onequarter of water. Therefore, this study focuses on residential and industrial sectors. ${ }^{10}$ On average, the supply capacity from ground water accounts for $28 \%$ of the total capacity, while this share varies from 0 to 100\% across cities. The unit cost of water supply ranges from CNY0.22 to CNY6.10 per ton with an average of CNY1.35. ${ }^{11}$ The cost levels will be compared to the water tariffs we collected next. For the rest of the water utility and urban variables, we note the dramatic gaps across city-years. For instance, Binzhou, a small eastern city, had only 760 water meters in 2002 while Tianjin, one of the four directlygoverned municipalities, had over 2.2 million meters in 2007. In terms of income level, the real GDP per capita in constant 2000 price was only CNY1,236 in the urban Chaoyang, a northeastern city, in 2002. In contrast, Zhenjiang, located in the affluent Yangtze River Delta area, had a per capita GDP of CNY221,000 (equivalent to $\$ 26,600$ ) by 2012.

8 There are county- or town-level utilities supplying water to suburban or rural areas. They are generally smaller and not included in our sample.

9 Accessed through data.cma.cn.

10 This is also because many cities did not report water sold to other sectors.

11 The exchange rate between the US dollar to Chinese yuan decreased from about CNY8.3 to CNY6.3 per US dollar between 2000 and 2012. Applying a rate of CNY7, the US dollar equivalent average unit cost is about $\$ 0.20$ cents. 
Table 1: Summary Statistics of Utility and City Characteristics

\begin{tabular}{|c|c|c|c|c|c|c|}
\hline Variables & $\mathrm{N}$ & $\begin{array}{c}\text { Year } \\
\text { Coverage }\end{array}$ & Mean & SD & Min & $\operatorname{Max}$ \\
\hline \multicolumn{7}{|l|}{ Utility characteristics } \\
\hline Total water supply $\left(10,000 \mathrm{~m}^{3}\right)$ & 1,771 & $2000-2007$ & $8,375.2$ & $11,488.2$ & 423.0 & $83,996.0$ \\
\hline Total water sold $\left(10,000 \mathrm{~m}^{3}\right)$ & 1,761 & $2000-2007$ & $6,641.3$ & $9,331.1$ & 281.0 & $67,543.0$ \\
\hline Water sold, residential $\left(10,000 \mathrm{~m}^{3}\right)$ & 1,772 & $2000-2007$ & $3,243.0$ & $4,566.7$ & 73.3 & $40,381.0$ \\
\hline Water sold, industrial $\left(10,000 \mathrm{~m}^{3}\right)$ & 1,694 & $2000-2007$ & $1,837.7$ & $2,560.4$ & 0.2 & $18,651.4$ \\
\hline Share of groundwater to total supply capacity & 1,712 & $2000-2007$ & 0.28 & 0.38 & 0.00 & 1.00 \\
\hline Cost per ton of water supply $\left(\mathrm{CNY} / \mathrm{m}^{3}\right)$ & 1,686 & $2000-2007$ & 1.35 & 0.65 & 0.22 & 6.10 \\
\hline Number of employees & 1,729 & $2000-2007$ & 885.5 & 964.2 & 59.0 & $10,959.0$ \\
\hline Total wage bill $(10,000 \mathrm{CNY})$ & 1,436 & 2001-2007 & $1,541.2$ & $2,153.9$ & 46.6 & $31,470.0$ \\
\hline Total pipe length $(\mathrm{km})$ & 1,501 & $2001-2007$ & 663.3 & 784.6 & 19.0 & $5,625.0$ \\
\hline Number of meters & 1,408 & 2001-2007 & 103,138 & 218,024 & 760 & $2,246,083$ \\
\hline Private sector participation indicator & 1,896 & $2000-2007$ & 0.18 & 0.39 & 0.00 & 1.00 \\
\hline \multicolumn{7}{|l|}{ City characteristics } \\
\hline Urban population $(10,000)$ & 3,120 & 2000-2012 & 137.8 & 164.7 & 17.5 & $1,779.1$ \\
\hline Urban population density (person per $\mathrm{km}^{2}$ ) & 3,119 & $2000-2012$ & $1,105.1$ & $1,000.3$ & 13.0 & $14,052.4$ \\
\hline Urban GDP per capita (CNY in 2000) & 2,394 & $2000-2012$ & $27,039.0$ & $19,238.2$ & $1,235.9$ & $220,945.6$ \\
\hline Agriculture share in urban GDP (\%) & 3,070 & 2000-2012 & 7.39 & 7.32 & 0.05 & 51.60 \\
\hline Industry share in urban GDP (\%) & 3,070 & $2000-2012$ & 51.09 & 11.67 & 14.37 & 92.30 \\
\hline Urban fiscal deficit (as \% of revenue) & 3,120 & $2000-2012$ & 1.00 & 1.49 & -1.00 & 44.84 \\
\hline Rainfall (mm) & 2,467 & 2000-2011 & 992.4 & 509.3 & 74.9 & $2,967.3$ \\
\hline Maximum temperature (Celsius degree) & 2,475 & $2000-2011$ & 37.4 & 2.5 & 24.3 & 43.7 \\
\hline Minimum temperature (Celsius degree) & 2,475 & 2000-2011 & -10.8 & 10.8 & -44.1 & 10.7 \\
\hline Annual inflation rate (\%) & 2,684 & $2000-2012$ & 2.33 & 2.52 & -4.7 & 21.2 \\
\hline
\end{tabular}

$\mathrm{CNY}=$ yuan, $\mathrm{GDP}=$ gross domestic product, $\mathrm{km}=$ kilometer, $\mathrm{km}^{2}=$ square kilometer, $\mathrm{m}^{3}=$ cubic meter, $\mathrm{mm}=$ millimeter, $\mathrm{N}=$ number, $\mathrm{SD}=$ standard deviation.

Note: Utility data are collected from the Annual Statistics of Urban Water Supply for the relevant years. City demographic and economic data are collected from the Chinese City Statistical Yearbooks for the relevant years. Weather data are collected from the China Meteorological Data Service Center at the station level and matched to the cities. Consumer price index data are collected from the Statistical Yearbooks of individual provinces.

Source: Authors' calculations.

Table 2 reports nominal and real water tariffs for residential and industrial users, respectively. We divide the sample into two time periods (i.e., 2000-2006 and 2007-2012), as the data come from two different sources and there is a slight discrepancy between them (discussed below). The average nominal residential water tariffs are CNY1.27 per ton for the period 2000-2006 and CNY1.60 for 2007-2012. Industrial water tariffs are higher at CNY1.66 and CNY2.21 over 2000-2006 and 20072012, respectively. The real tariffs in 2000 prices are slightly lower than the nominal tariffs. This is not surprising given that inflation rates have been moderate during the period. 
Table 2: Summary Statistics of Water Tariffs

\begin{tabular}{lcccccc}
\hline Sector/Years & $\mathrm{N}$ & $\begin{array}{c}\text { Number } \\
\text { of Cities }\end{array}$ & Mean & SD & Min & Max \\
\hline $\begin{array}{l}\text { Residential } \\
\quad \text { Year 2000-2006 }\end{array}$ & & & & & & \\
$\quad$ Nominal & 1,391 & 211 & 1.27 & 0.45 & 0.45 & 3.00 \\
$\quad$ Real & 1,342 & 207 & 1.23 & 0.42 & 0.45 & 2.93 \\
$\quad$ Year 2007-2012 & & & & & & \\
$\quad$ Nominal & 1,266 & 233 & 1.60 & 0.47 & 0.75 & 4.82 \\
$\quad$ Real & 1,026 & 180 & 1.29 & 0.40 & 0.62 & 3.70 \\
$\quad \begin{array}{l}\text { Industrial } \\
\quad \text { Year 2000-2006 }\end{array}$ & & & & & & \\
$\quad$ Nominal & 1,388 & 211 & 1.66 & 0.76 & 0.59 & 6.00 \\
$\quad$ Real & 1,339 & 207 & 1.61 & 0.73 & 0.59 & 6.00 \\
$\quad$ Year 2007-2012 & & & & & & \\
$\quad$ Nominal & 1,263 & 233 & 2.21 & 0.96 & 0.90 & 7.85 \\
$\quad$ Real & 1,024 & 180 & 1.78 & 0.80 & 0.70 & 6.05 \\
\hline
\end{tabular}

$\mathrm{N}=$ number, $\mathrm{SD}=$ standard deviation.

Note: Water tariffs are collected from the Annual Statistics of Urban Water Supply for the period 2000-2006 and China's Water Net from 2007 to 2012. Yearly data are simple averages of the monthly data from China's Water Net. Real tariffs are in 2000 prices.

Source: Authors' calculations.

Figure 1 shows the time trends of national average tariffs for residential and industrial users in nominal and real terms. The trajectories of average tariffs within each subperiod appear smooth and generally increase despite a downward break between 2006 and 2007, which probably arises from different measuring standards used by our two data sources. A few patterns are noteworthy regarding the dynamics of tariff setting. First, the growth rates of nominal tariffs are relatively high, registering around 8\% for both sectors, before 2007 and drop to 3.5\% for residential and 5.1\% for the industrial sectors after 2007. One plausible explanation is that local governments, concerned with the adverse effects of the global financial crisis, slowed down the tariff increase to help cope with possible economic hardship. Second, the growing patterns of real tariffs followed those of nominal tariffs closely before 2007. Removing inflation factors, the tariffs have increased at $6.6 \%$ and $7.3 \%$ per annum on average for residential and industrial sectors, respectively. However, real tariffs largely stayed unchanged between 2007 and 2012. Finally, while industrial tariffs are higher than residential tariffs, the trends of both appear to be parallel. 
Figure 1: Time Trends for Nominal and Real Water Tariffs, 2000-2012

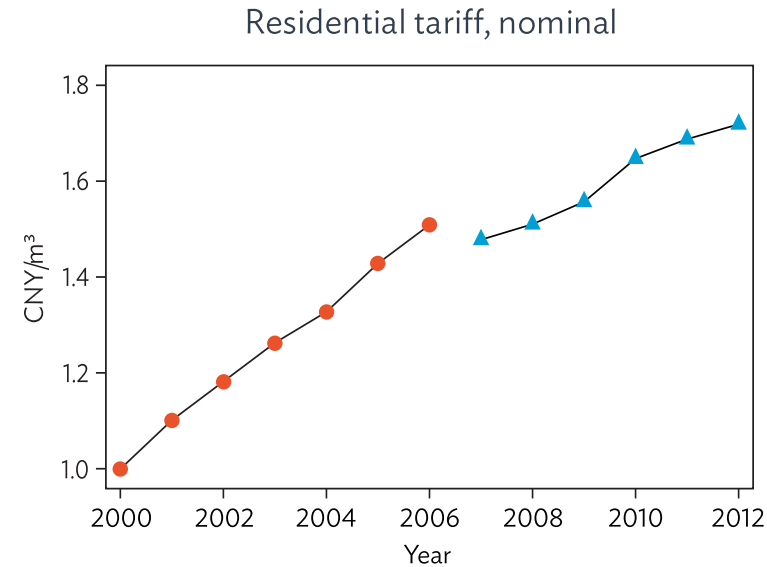

Industrial tariff, nominal

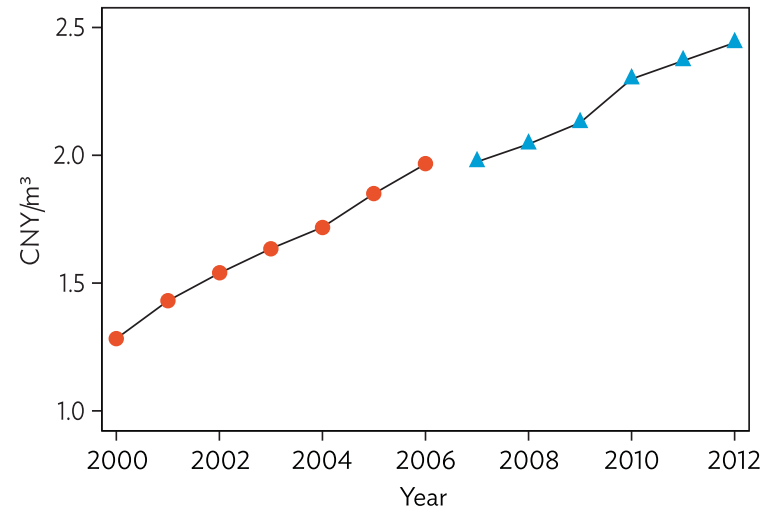

$\longrightarrow-2000-2006$

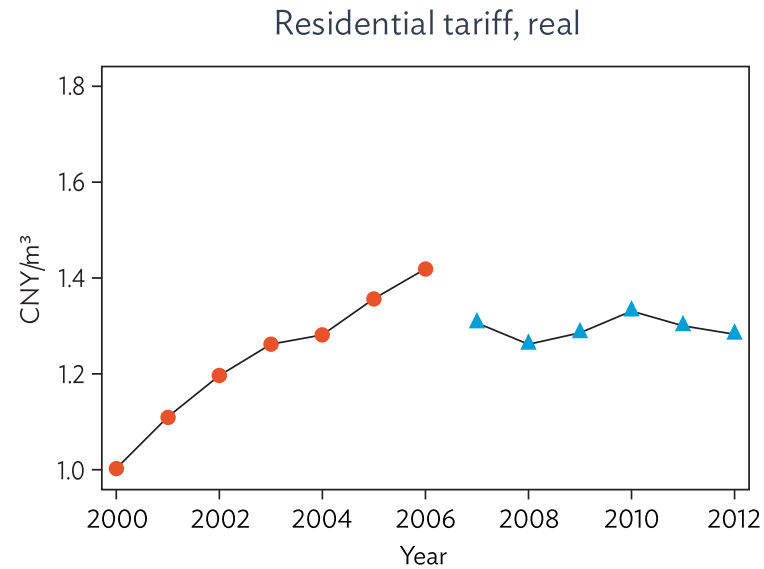

Industrial tariff, real

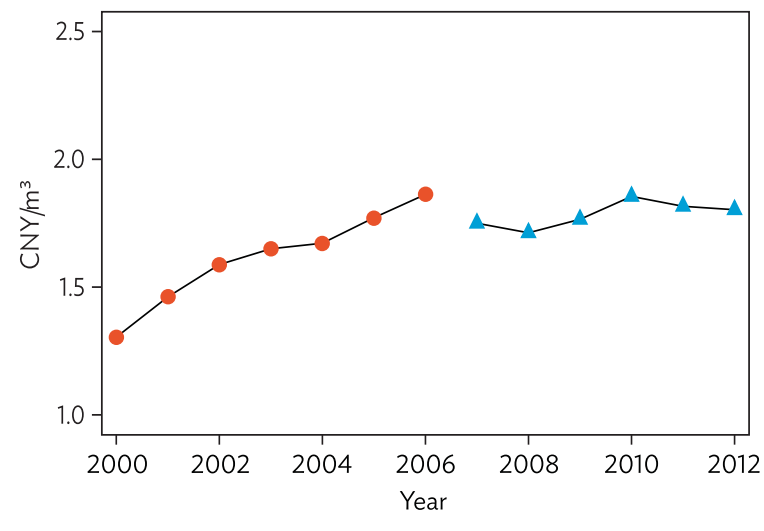

$\mathrm{CNY}=$ yuan, $\mathrm{m}^{3}=$ cubic meter.

Note: Real tariffs are in 2000 prices.

Source: Authors' calculations.

Table 3 compares the nominal tariffs and utility-reported average water supply costs by year. The tariffs are averaged across residential and industrial sectors with the amount of water provided to each sector as weights. It shows that by 2003 , utilities that had sufficient revenues to cover costs outnumbered cities running deficits. The situation was slightly reversed in 2004 and 2006, and largely in 2007. Note, however, that the numbers of deficit cases are possibly overestimated since, due to lack of quantity data, the average weighted tariffs do not yet incorporate tariffs for commercial, administrative, and special sectors, which are commonly higher than residential tariffs. In sum, the comparison suggests that cases where water tariffs are below water supply costs are far from ubiquitous across the country. 
Table 3: Average Weighted Tariffs versus Average Costs

\begin{tabular}{|c|c|c|c|c|c|}
\hline \multirow[b]{2}{*}{ Year } & \multicolumn{2}{|c|}{$\mathrm{AWT}>=\mathrm{AC}$} & \multicolumn{2}{|c|}{$\mathrm{AWT}<\mathrm{AC}$} & \multirow{2}{*}{$\begin{array}{c}\text { All } \\
\text { Average } \\
\text { Difference }\end{array}$} \\
\hline & $\begin{array}{l}\text { Number } \\
\text { of Cities }\end{array}$ & $\begin{array}{c}\text { Average } \\
\text { Difference }\end{array}$ & $\begin{array}{l}\text { Number } \\
\text { of Cities }\end{array}$ & $\begin{array}{c}\text { Average } \\
\text { Difference }\end{array}$ & \\
\hline 2000 & 139 & 0.31 & 69 & -0.24 & 0.13 \\
\hline 2001 & 135 & 0.37 & 68 & -0.26 & 0.16 \\
\hline 2002 & 111 & 0.38 & 79 & -0.25 & 0.11 \\
\hline 2003 & 114 & 0.38 & 81 & -0.32 & 0.09 \\
\hline 2004 & 94 & 0.35 & 109 & -0.33 & -0.01 \\
\hline 2005 & 111 & 0.46 & 97 & -0.37 & 0.07 \\
\hline 2006 & 93 & 0.56 & 95 & -0.39 & 0.08 \\
\hline 2007 & 80 & 0.39 & 110 & -0.41 & -0.07 \\
\hline
\end{tabular}

$\mathrm{AC}=$ average cost, $\mathrm{AWT}$ = average weighted tariff.

Notes: AWT with water supply to each sector as weight. Excluding cities with missing residential or industrial water tariffs or quantities.

Source: Authors' calculations.

\section{URBAN WATER TARIFF SETTING}

Urban water tariff here refers to the price charged by the water utility on consumers who obtain water from the urban water supply network operated by the utility. Charging water tariffs can be traced back to 1985 in the PRC, when the government started to require that water supply acquired through any hydraulic works should be paid. ${ }^{12}$ In 1994, the government issued the PRC Ordinance on Urban Water Supply, detailing the water supply pricing scheme such as the consumer categories, the tariff structure and formula, and the administrative procedure of setting tariffs. The objective was to have water supply costs fully covered by tariff revenues. Further, the PRC Water Law enacted in 1998 proposed to charge a water resource fee to protect water resources and improve water use efficiency (Zhong and Mol 2010). Usually, the water utility pays the hydraulic work charge and water resource fee when it obtains water from the sources and counts them as part of its water supply cost.

The urban water tariff is primarily set by the prefecture government and is supposed to cover the cost of supplying water, taxes, and a reasonable amount of profit for the water utility. The water supply cost covers the costs for water acquisition, production, transmission, and distribution, and other related costs. The water utility is responsible for collecting water tariffs, which constitutes the major revenue for the utility. In a separate process, the prefecture government also sets the level of wastewater treatment fee. The water utility collects the wastewater treatment fees together with water tariffs and transfers the former to the sewage company.

The PRC Price Law passed in 1998 provides that a public hearing system must be established in setting prices for public utilities, services in public interest, and goods produced by natural monopoly by the government. Following this legislation, the central government issued a few decrees to introduce public hearings on price setting by governments, including the setting of urban water tariffs. ${ }^{13}$

12 See State Council's No. 94 Policy Paper Administrative Decree on Accounting, Collecting and Managing the Raw Water Charges of Hydraulic Works in 1985.

13 There is the Implementation of Public Hearing for Government to Set Prices in 2002 and the Rule of Conduct of Government to Set Prices in 2006, among others. 
Public hearings on water tariffs, which have been largely focused on residential water tariffs, have received considerable media and public attention since the policy implementation.

The proposal for a new (higher) water tariff is generally initiated by the water utility in order to cover its investment and/or increased costs. In response, relevant government agencies such as the planning agency, water affairs department and/or price bureau will conduct consultation and assessment regarding the reasonability and impacts of the tariff increase. The government will proceed to call a public hearing unless it decides to reject the proposal outright. Resident delegates are selected to participate in the public hearing and vote on the proposal at the end of the hearing.

From the above description, we can see that the decision process on water tariff setting primarily involves the water utility, government, and water users. Each party has relatively clear roles to play in the process. However, people argue that the process is largely controlled by the local government for several reasons. First, the majority of water utilities are owned by the government despite a movement in early the 1990s toward private sector participation in urban water services in the PRC (Jiang and Zheng 2014). Second, the prefectural government could reject the tariff adjustment proposal directly without convening a public hearing. Third, it is shown that governments have definitive control on the size and composition of the delegation as well as the ways the delegates are selected to participate in the hearings. In a few cases studied by Zhong and Mol (2008), the majority of delegates were government employees or from institutions affiliated with the government. Independent citizens only accounted for a small minority in the delegation. Thus, it is not surprising to see that most proposals for water tariff increase submitted for public hearings were approved. However, it is noteworthy that the public hearing is not always a token activity. There are quite a few cases wherein the public rejected the price increase proposals or got the proposals revised (Zhong and Mol 2008).

\section{A. Empirical Model}

We estimate a set of regression models to understand the factors that may influence water tariff setting at the city level. To the extent that the local government plays a dominant role in the whole process, our results primarily reveal the factors that government officials have considered in setting new water tariffs. The baseline equation is

$$
\ln P_{i t}=\alpha_{0}+X_{i t} \beta+\gamma_{i}+\delta_{p} t+\varepsilon_{i t},
$$

where $P_{i t}$ is the nominal or real water tariff of city $i$ in year $t, X_{i t}$ is a vector of time-varying city characteristics that are probably exogenous and could affect the level of water tariff, $\gamma_{i}$ is the city fixed effect, and $\delta_{p} t$ represents the province-specific trend in setting water tariffs. When nominal water tariff is the dependent variable, the economic covariates are all expressed in nominal terms and the annual inflation rate is included as an explanatory variable. For real water tariff, the explanatory covariates are converted into real terms.

The city characteristics we are interested in include total population (log), population density (log), agricultural and industrial shares of GDP, GDP per capita, fiscal deficit as a share of revenue, 5-year moving averages of precipitation (log), and maximum temperature and minimum temperature. Total population proxies for demand for water and would be positively correlated with water price, other things being equal. On the other hand, a larger population suggests scale of economy and thus lowers the cost of water supply. Higher population density means lower unit cost of serving individual 
water users. Agriculture remains a water-intensive sector in the PRC. To ensure sufficient water is allocated to agricultural production, the prefectural government may have to increase water tariffs to depress residential and industrial use. GDP per capita is expected to be positively correlated with water tariff, as higher income level implies more willingness to pay for water services as well as greater water demand leading to government adopting higher tariffs. It is likely for a local government to cut the subsidy to water utilities and raise water tariffs when it runs into a serious deficit. Continuous significant rainfall and low temperature tend to keep the demand for water at a relatively low level, while high temperature does the opposite. Thus, these weather-related factors may have been considered in tariff setting in order to balance the water supply and demand.

Besides these conventional factors, we introduce a new explanatory variable, namely the average tariffs of peer cities. Here, we define peer cities as those from the same province and neighboring a primary city. Specifically, we include $\ln \left(\sum_{j \neq i} \sigma_{j i} P_{j t}\right)$ on the right-hand side of equation (1) where

$$
\sigma_{j i}=\left\{\begin{array}{cl}
\frac{1}{n_{i}} & \text { If city } j \text { is one of the } n_{i} \text { cities from the same province and neighboring city } i \\
0 & \text { Otherwise. }
\end{array}\right.
$$

Conceptually, a city government could be affected by its peers in choosing water tariff levels for different reasons. While government officials and the public are involved in the price setting process, they do not observe the true costs of supplying water by the utility. To reduce this information asymmetry, decision makers may take into account the fact that water service costs should be similar across neighboring cities that share common natural and economic conditions. Hence, a new tariff significantly higher than the peer cities' tariffs is likely to be viewed as an indication of inefficiency in the local utility's operation and can get rejected. This is referred to as yardstick competition in the tax setting literature (e.g., Besley and Case 1995). The influence of peer cities may also arise from a different type of competition whereby cities lower their water tariffs to attract water-intensive industries. We consider this second explanation less likely since producers using large amount of water as their inputs often extract water independently and are subject to separate pricing policies. Neither does the argument seem to apply to residential water tariffs as a Tiebout model would suggest. Since water expenditure accounts for a fairly small portion of living costs in the PRC, people are very unlikely to move between cities because of water tariffs. ${ }^{14}$

In addition to the baseline model, we try three different variants. First, we add 1-year lag water tariff (log) to account for the likely practice that the decision to adjust water tariffs are partly associated with existing tariff levels. We also substitute year fixed effects for the province-specific time trend to control for common time effects as well as the fact that the tariff data come from two sources covering different periods. Lastly, we try an alternative definition of peer cities as all other cities in the same province and use their average tariff to measure peer effects.

\section{B. Results}

Table 4(a) reports the estimation results for residential water tariff regressions. Nominal tariffs are examined in columns (1)-(4), controlling for the contemporary inflation rate, while real tariffs are in columns (5)-(8). First of all, the average tariff of peer cities exhibits a strong positive impact on the

14 The tax setting literature offers a third explanation for the interjurisdiction peer effects: expenditure spillovers. This, however, does not seem to be relevant to water tariff setting. 
primary city's tariff with a statistical significance at the $1 \%$ level. The baseline estimates suggest that a $10 \%$ increase in the average tariff of neighboring cities from the same province leads to a $4.1 \%$ increase in a city's tariff level in the nominal case and $5.2 \%$ increase in the real case. The elasticity drops to about 0.28 but remains statistically significant when we control for the lagged tariff of the primary city and further replace the interaction of province dummy and time trend with year fixed effects. Columns (4) and (8) show that this peer effect continues to hold when we expand the definition of peer cities to all other cities from the same province (not necessarily neighboring). To put the estimates in perspective, in setting water tariffs, a city is as responsive to its peers' average as to its own lagged price.

Most coefficients of city characteristics have the expected signs and are generally stable across nominal and real models and across different specifications, though only a few of them are statistically significant. For example, population and population density are negatively correlated with water tariffs, suggesting that tariff setting takes into account the lower costs of serving water to a larger population and to a population located more closely. A higher share of output in agriculture is associated with higher water tariffs, and the estimates are much greater than those for industrial output share. This implies that agriculture plays a significant role in local water allocation, and water tariff may have been used to allocate more water to the agricultural sector from urban use. Cities with high fiscal deficits tend to have high water tariffs since the governments are less capable of subsidizing water services. Correlations between weather variables (i.e., temperature and rainfall) and tariff levels are not strong. Again, the above interpretations are tentative since most estimates lack statistical significance. The current tariff level is closely related to the 1-year lag of tariff. The elasticity is estimated between 0.45 and 0.50 , indicating a convergence trend of tariff levels across cities.

Contrary to expectation, GDP per capita has a negative and statistically significant effect on the tariff level although the magnitude is small (i.e., 10\% increase in per capita GDP resulting in about $0.3 \%$ decrease in residential water tariffs). One possible explanation is that, holding other factors constant, more economically advanced cities can supply water more efficiently (e.g., less nonrevenue water) and thus entail lower service cost.

Table 4(b) presents the regression estimates for industrial water tariffs. The estimated elasticity of the city's own tariff with respect to the average industrial tariff of peer cities ranges from 0.15 to 0.33 , which is significant at the $1 \%$ level and smaller than that of residential tariffs estimated between 0.25 and 0.52. Hence, similar to the case of residential tariffs, the average level of the peer cities' industrial water tariffs plays a prominent role in a city's decision on its own tariff for industrial use. For other city characteristics, the results bear similar overall patterns as those for residential tariffs. For instance, the lagged tariff also has a notable influence in setting current industrial tariff. One exception is that the correlation between GDP per capita becomes smaller in magnitude, although still negative, and statistically insignificant. 
Table 4: Water Tariff Regressions

(a) Residential

\begin{tabular}{|c|c|c|c|c|c|c|c|c|}
\hline Variables & $(1)$ & $(2)$ & (3) & $(4)$ & (5) & $(6)$ & $(7)$ & $(8)$ \\
\hline \multirow[t]{2}{*}{ Log (average tariff of peer cities) } & $0.407^{* * *}$ & $0.251^{* * *}$ & $0.286^{* * *}$ & $0.431^{* * *}$ & $0.519^{* * *}$ & $0.280^{* * *}$ & $0.288^{* * *}$ & $0.457^{* * *}$ \\
\hline & $(0.0875)$ & $(0.0772)$ & $(0.0606)$ & $(0.0936)$ & $(0.0755)$ & $(0.0713)$ & $(0.0632)$ & $(0.0794)$ \\
\hline \multirow[t]{2}{*}{ Log (urban GDP per capita) } & -0.0339 & $-0.0345^{* *}$ & $-0.0374^{* *}$ & $-0.0300^{* *}$ & -0.00311 & -0.0265 & $-0.0347^{* *}$ & $-0.0288^{*}$ \\
\hline & $(0.0245)$ & $(0.0166)$ & $(0.0153)$ & $(0.0151)$ & $(0.0259)$ & $(0.0178)$ & $(0.0167)$ & $(0.0162)$ \\
\hline \multirow[t]{2}{*}{ GDP agriculture share } & 0.00172 & 0.00125 & 0.000726 & 0.00122 & 0.00379 & 0.00276 & 0.00107 & 0.00218 \\
\hline & $(0.00253)$ & $(0.00196)$ & $(0.00183)$ & $(0.00165)$ & $(0.00279)$ & $(0.00185)$ & $(0.00185)$ & $(0.00173)$ \\
\hline \multirow[t]{2}{*}{ GDP industry share } & $3.64 \mathrm{e}-05$ & 0.000258 & 0.000507 & 0.000288 & $-5.23 e-05$ & -0.000233 & 0.000169 & $4.62 e-05$ \\
\hline & $(0.00137)$ & $(0.000884)$ & $(0.000746)$ & $(0.000820)$ & $(0.00150)$ & $(0.000960)$ & $(0.000818)$ & $(0.000901)$ \\
\hline \multirow[t]{2}{*}{ Log (urban population) } & 0.00127 & -0.0214 & $-0.0441^{*}$ & -0.0342 & 0.0284 & -0.0122 & -0.0333 & -0.0283 \\
\hline & $(0.0459)$ & $(0.0279)$ & $(0.0253)$ & $(0.0247)$ & $(0.0503)$ & $(0.0295)$ & $(0.0268)$ & $(0.0277)$ \\
\hline \multirow[t]{2}{*}{ Log (urban population density) } & -0.0190 & -0.0107 & -0.00474 & -0.0137 & -0.0182 & -0.0116 & -0.00533 & -0.0146 \\
\hline & $(0.0198)$ & $(0.0123)$ & $(0.0112)$ & $(0.0127)$ & $(0.0211)$ & $(0.0134)$ & $(0.0117)$ & $(0.0134)$ \\
\hline \multirow[t]{2}{*}{ Fiscal deficit as a share of revenue } & 0.000370 & 0.00193 & 0.00358 & 0.000977 & -0.000502 & 0.000643 & 0.00393 & 0.000266 \\
\hline & $(0.00501)$ & $(0.00429)$ & $(0.00384)$ & $(0.00444)$ & $(0.00562)$ & $(0.00468)$ & $(0.00404)$ & $(0.00509)$ \\
\hline \multirow[t]{2}{*}{ Log (5-year MA rainfall) } & 0.0445 & 0.0457 & 0.00538 & 0.0491 & 0.0823 & 0.0760 & 0.0357 & 0.0736 \\
\hline & $(0.0732)$ & $(0.0493)$ & $(0.0462)$ & $(0.0432)$ & $(0.0822)$ & $(0.0527)$ & $(0.0513)$ & $(0.0474)$ \\
\hline \multirow[t]{2}{*}{ Maximum temperature (5-year MA) } & 0.0146 & -0.00468 & -0.00769 & -0.00269 & $0.0258^{* *}$ & -0.00267 & -0.00113 & 0.000381 \\
\hline & $(0.00995)$ & $(0.00609)$ & $(0.00703)$ & $(0.00562)$ & $(0.0115)$ & $(0.00792)$ & $(0.00873)$ & $(0.00753)$ \\
\hline \multirow[t]{2}{*}{ Minimum temperature (5-year MA) } & -0.00673 & -0.00250 & 0.000155 & -0.00274 & $-0.0109^{*}$ & -0.00401 & -0.00106 & -0.00366 \\
\hline & $(0.00567)$ & $(0.00409)$ & $(0.00416)$ & $(0.00397)$ & $(0.00618)$ & $(0.00465)$ & $(0.00465)$ & $(0.00448)$ \\
\hline \multirow[t]{2}{*}{ Time trend } & $0.0260^{* * *}$ & $0.0128^{* *}$ & & 0.00450 & 0.00523 & 0.00255 & & 0.000650 \\
\hline & $(0.00817)$ & $(0.00553)$ & & $(0.00584)$ & $(0.00682)$ & $(0.00431)$ & & $(0.00498)$ \\
\hline \multirow[t]{2}{*}{ Log (inflation rate) } & $0.293^{* *}$ & 0.0198 & 0.0394 & -0.0356 & & & & \\
\hline & $(0.120)$ & $(0.106)$ & $(0.128)$ & (0.101) & & & & \\
\hline \multirow[t]{2}{*}{ Log (residential tariff), 1-year lag } & & $0.478^{* * *}$ & $0.503^{* * *}$ & $0.475^{* * *}$ & & $0.470^{* * *}$ & $0.503^{* * *}$ & $0.448^{* * *}$ \\
\hline & & $(0.0290)$ & $(0.0315)$ & $(0.0281)$ & & $(0.0327)$ & $(0.0342)$ & $(0.0322)$ \\
\hline Observations & 2,042 & 1,885 & 1,885 & 2,048 & 1,825 & 1,668 & 1,668 & 1,796 \\
\hline Adj. R-squared & 0.839 & 0.878 & 0.877 & 0.884 & 0.807 & 0.860 & 0.860 & 0.868 \\
\hline \multicolumn{9}{|l|}{ Controls } \\
\hline City dummy & Y & Y & Y & Y & Y & Y & Y & Y \\
\hline Year dummy & $\mathrm{N}$ & $\mathrm{N}$ & Y & $\mathrm{N}$ & $N$ & $\mathrm{~N}$ & Y & $\mathrm{N}$ \\
\hline Province $\mathrm{x}$ time trend & Y & Y & $\mathrm{N}$ & Y & Y & Y & $\mathrm{N}$ & Y \\
\hline
\end{tabular}




\begin{tabular}{|c|c|c|c|c|c|c|c|c|}
\hline Variables & (1) & (2) & (3) & (4) & (5) & (6) & (7) & (8) \\
\hline \multirow[t]{2}{*}{ Log (neighbor peer tariff) } & $0.231^{* * *}$ & $0.150^{* *}$ & $0.231^{* * *}$ & $0.252^{* * *}$ & $0.326^{* * *}$ & $0.181^{* * *}$ & $0.235^{* * *}$ & $0.293^{* * *}$ \\
\hline & $(0.0802)$ & $(0.0638)$ & $(0.0601)$ & $(0.0905)$ & $(0.0794)$ & $(0.0648)$ & $(0.0664)$ & $(0.0860)$ \\
\hline \multirow[t]{2}{*}{ Log (urban GDP per capita) } & -0.0142 & -0.0168 & -0.0141 & -0.0199 & 0.0220 & -0.00871 & -0.00685 & -0.0174 \\
\hline & $(0.0321)$ & $(0.0241)$ & $(0.0218)$ & $(0.0237)$ & $(0.0370)$ & $(0.0262)$ & $(0.0238)$ & $(0.0257)$ \\
\hline \multirow{2}{*}{ GDP agriculture share } & 0.00229 & 0.00277 & 0.00239 & 0.00115 & $0.00567^{*}$ & $0.00494^{*}$ & 0.00276 & 0.00237 \\
\hline & $(0.00337)$ & $(0.00276)$ & $(0.00272)$ & $(0.00230)$ & $(0.00326)$ & $(0.00266)$ & $(0.00276)$ & $(0.00242)$ \\
\hline \multirow[t]{2}{*}{ GDP industry share } & -0.00174 & -0.000338 & -0.000588 & 0.000266 & -0.00174 & -0.000579 & -0.000899 & 0.00014 \\
\hline & $(0.00142)$ & $(0.00103)$ & $(0.000837)$ & $(0.00101)$ & $(0.00156)$ & $(0.00109)$ & $(0.000902)$ & $(0.00106)$ \\
\hline \multirow[t]{2}{*}{ Log (urban population) } & 0.0387 & 0.0153 & -0.0267 & 0.00699 & 0.0599 & 0.0178 & -0.0159 & 0.0119 \\
\hline & $(0.0547)$ & $(0.0341)$ & $(0.0380)$ & $(0.0301)$ & $(0.0594)$ & $(0.0354)$ & $(0.0412)$ & $(0.0327)$ \\
\hline \multirow[t]{2}{*}{ Log (urban population density) } & -0.0126 & 0.00242 & 0.00845 & -0.00502 & -0.0106 & 0.000366 & 0.00870 & -0.00848 \\
\hline & $(0.0196)$ & $(0.0146)$ & $(0.0147)$ & $(0.0147)$ & $(0.0224)$ & $(0.0157)$ & $(0.0150)$ & $(0.0160)$ \\
\hline \multirow[t]{2}{*}{ Fiscal deficit as a share of revenue } & 0.00496 & 0.00176 & 0.00507 & 0.000484 & 0.00591 & -0.000362 & 0.00547 & 0.000157 \\
\hline & $(0.00690)$ & $(0.00639)$ & $(0.00532)$ & $(0.00640)$ & $(0.00663)$ & $(0.00703)$ & $(0.00548)$ & $(0.00695)$ \\
\hline \multirow[t]{2}{*}{ Log (5-year moving average rainfall) } & 0.0657 & 0.0135 & -0.0180 & 0.0191 & 0.0944 & 0.0314 & 0.00961 & 0.0328 \\
\hline & $(0.0817)$ & $(0.0659)$ & $(0.0609)$ & $(0.0622)$ & $(0.0873)$ & $(0.0723)$ & $(0.0695)$ & $(0.0685)$ \\
\hline \multirow[t]{2}{*}{ Maximum temperature (5-year MA) } & 0.0140 & -0.00881 & -0.0107 & -0.00295 & $0.0276^{* *}$ & -0.00787 & -0.00348 & -0.000696 \\
\hline & $(0.0117)$ & $(0.00881)$ & $(0.00953)$ & $(0.00852)$ & $(0.0128)$ & $(0.0116)$ & $(0.0118)$ & $(0.0116)$ \\
\hline \multirow[t]{2}{*}{ Minimum temperature (5-year MA) } & -0.00578 & -0.00104 & 0.00211 & -0.00129 & -0.0111 & -0.00245 & 0.00158 & -0.00168 \\
\hline & $(0.00730)$ & $(0.00497)$ & $(0.00527)$ & $(0.00521)$ & $(0.00847)$ & $(0.00565)$ & $(0.00577)$ & $(0.00584)$ \\
\hline \multirow[t]{2}{*}{ Time trend } & $0.0299^{* * *}$ & $0.0160^{* *}$ & & 0.00818 & 0.00449 & 0.00258 & & -0.00144 \\
\hline & (0.0101) & $(0.00777)$ & & $(0.00777)$ & $(0.00899)$ & $(0.00636)$ & & $(0.00664)$ \\
\hline \multirow[t]{2}{*}{ Log (inflation rate) } & 0.114 & -0.0135 & 0.0786 & -0.0880 & & & & \\
\hline & $(0.173)$ & $(0.156)$ & $(0.193)$ & $(0.148)$ & & & & \\
\hline \multirow[t]{2}{*}{ Log (industrial tariff), 1-year lag } & & $0.445^{* * *}$ & $0.477^{* * *}$ & $0.465^{* * *}$ & & $0.431^{* * *}$ & $0.468^{* * *}$ & $0.447^{* * *}$ \\
\hline & & $(0.0593)$ & $(0.0597)$ & $(0.0583)$ & & $(0.0593)$ & $(0.0652)$ & $(0.0591)$ \\
\hline Observations & 2,039 & 1,880 & 1,880 & 2,039 & 1,822 & 1,663 & 1,663 & 1,789 \\
\hline Adj. R-squared & 0.855 & 0.905 & 0.902 & 0.904 & 0.828 & 0.891 & 0.888 & 0.890 \\
\hline \multicolumn{9}{|l|}{ Controls } \\
\hline City dummy & Y & Y & $\mathrm{Y}$ & Y & Y & Y & Y & Y \\
\hline Year dummy & $\mathrm{N}$ & $\mathrm{N}$ & $\mathrm{Y}$ & $\mathrm{N}$ & $\mathrm{N}$ & $\mathrm{N}$ & Y & $\mathrm{N}$ \\
\hline Province $\mathrm{x}$ time trend & Y & $Y$ & $N$ & $Y$ & $Y$ & $Y$ & $\mathrm{~N}$ & $Y$ \\
\hline
\end{tabular}

$\mathrm{GDP}=$ gross domestic product, $\mathrm{MA}=$ moving average, $\mathrm{N}=$ no, $\mathrm{Y}=$ yes.

Note: The dependent variable is log (industrial water tariff) with nominal tariff in columns (1)-(4) and real tariffs in columns (5)-(8). Nominal (real) GDP per capita and lag tariff are used in columns (1)-(4) ([5]-[8]). Peer cities refer to neighboring cities from the same province in columns (1)-(3) and (5)-(7), and cities from the same province in columns (4) and (8). Standard errors in parentheses are clustered at the city level. ${ }^{* *} p<0.01,{ }^{* *} p<0.05$, and ${ }^{*} p<0.1$.

Source: Authors' calculations. 


\section{WATER DEMAND ESTIMATION}

In this section, we estimate water demand functions with city-level data on water consumption and tariffs. While it is more common in the literature to estimate residential water demand functions with household data, the two approaches answer different questions and complement each other. For local government planning and managing water resources, it is not sufficient to have an average estimate of household price elasticity of water demand in the presence of considerable heterogeneity across households. Moreover, it is rare to have firm-level water use data to estimate water demand by industrial users. City-level estimation is better positioned to answer the question of how aggregate water demand would respond to a price change as well as changes in other relevant factors.

What we do here is closer to the few studies that use city or community-level data to estimate water demand elasticities, such as Bell and Griffin (2008, 2011); Diakite, Semenov, and Thomas (2009); Renzetti (1999); and Timmins (2002). However, it is worth highlighting a few distinctive features of our work. First, we use a large sample of cities from a developing country, while the existing studies, other than Diakite, Semenov, and Thomas (2009), focus on developed countries (mainly the US and Canada). Residential water consumption patterns in the PRC could be distinct from these countries. Second, we also estimate industrial water demand elasticities across cities, which is not common in the literature. Third, we address the endogeneity of water tariffs in the demand models by instrumenting a city's own water tariff with its peer cities' average tariff. This strategy, to be elaborated below, is novel to the best of our knowledge.

\section{A. Empirical Model}

We estimate a log-log demand function for both residential and industrial sectors. The baseline specification is

$$
\ln y_{i t}=\alpha_{0}+\beta_{1} \ln P_{i t}+X_{i t} \varphi+\gamma_{i}+\delta_{p} t+\omega_{i t}
$$

where $y_{i t}$ is total water consumption by residential or industrial sector of city $i$ in year $t$; $P_{i t}$ is the real water tariff for residential or industrial sector; ${ }^{15} X_{i t}$ is a vector of time-varying urban factors that may affect water consumption exogenously, including population, population density, agricultural and industrial shares of GDP, real GDP per capita, contemporary rainfall, and maximum and minimum temperature of the year; $\gamma_{i}$ is the city fixed effect; and $\delta_{p} t$ represents the province-specific trends in water consumption.

The primary parameter of interest is $\beta_{1}$, which, presumably negative, measures the price elasticity of water demand. However, the OLS estimation of equation (2) is likely to yield a biased estimate of the elasticity even with the set of controls in the model. One primary source of endogeneity arises when decision makers incorporate expected water demand in setting water tariffs.

15 In the PRC, the price of water paid by consumers should be the sum of water tariff and the rate of sewage charge, as sewage fee is collected in the same bill of water tariff. Unfortunately, we do not have data on sewage rates before 2007. The post-2007 data suggest that sewage rates are relatively low compared to the water tariffs and have been adjusted infrequently. To the extent that the sewage rates are considered as a small constant added to the water tariffs before 2007, a change in tariff could represent the marginal change in the total water price. Thus, our estimates with tariff only should not be considerably biased. Alternatively, we impute the sewage rates before 2007 based on linear projections for each city and add them to the water tariffs. The resulting estimation confirms the general patterns of the estimates with tariffs only (i.e., larger negative elasticity by IV estimation), but the estimates for the industrial sector are subject to weak IV problem. These estimates are available from authors upon request. 
Specifically, the water tariffs may be increased in the expectation of high water demand, which is positively correlated with the realized water demand. In such a case, the OLS estimate of $\beta_{1}$ is biased upward toward 0 or even positive while the true value should be negative. However, the endogeneity problem plaguing models estimated with household data and quantity-based pricing wherein the consumed quantity and marginal price of water are simultaneously determined (e.g., Foster and Beattie 1981; Olmstead, Hanemann, and Stavins 2007) seems less of a concern in our case. First, most cities applied a flat tariff rate in the 2000s in the PRC. Zhang, Fang, and Baerenklau (2017) document that there were only 28 out of a total of 138 cities in the PRC adopting increasing block tariffs by 2009 since the approach was introduced in 2002. Second, urban household size is generally small in the PRC, so the maximum quantity eligible for a base tariff is less likely binding for the majority of households in cities adopting increasing block tariffs. Thus, the base tariff rate should play a dominant role in determining water demand of individual households as well as a city's aggregate demand. Third, a long debate exists in the literature regarding whether consumers respond to marginal or average price. A few recent studies convincingly show that consumers are more sensitive to the average price rather than the marginal price in utility consumption (Ito 2014, Wichman 2014).

To tackle the above endogeneity problem, we employ the average water price of peer cities, denoted as $\ln \left(\sum_{j \neq i} \sigma_{j i} P_{j t}\right)$, to instrument for the city's own water price $\ln P_{i t}$. The results in the previous section suggest that there exists a strong tariff mimicking practice among cities that are from the same province and share boundaries. Hence, despite slight differences between equations (1) and (2), the average peer price should still be positively correlated with the own water price. Meanwhile, there is no compelling reason to think that other cities' tariff levels would affect a city's own water consumption, especially when the estimation is conditional on the province-specific time trends, which control for the common time patterns in both water tariff setting and water consumption within a province. $^{16}$ Therefore, we consider that the average peer price satisfies both conditions for an IV.

Equation (2) imposes constant elasticity to the demand function. To relax this, we also estimate a quadratic-price specification:

$$
\ln y_{i t}=\alpha_{0}+\beta_{1} \ln P_{i t}+\beta_{2} \ln ^{2} P_{i t}+X_{i t} \varphi+\gamma_{i}+\delta_{p} t+\omega_{i t}
$$

which allows the price elasticity to vary by water price. The two endogenous price variables are instrumented by $\ln \left(\sum_{j \neq i} \sigma_{j i} P_{j t}\right)$ and $\ln ^{2}\left(\sum_{j \neq i} \sigma_{j i} P_{j t}\right)$. To assess the extent to which common provincial shocks affect both water tariff setting and water demand, we also estimate models that substitute the year fixed effect for the province-specific time trends and compare the results.

\section{B. Results}

Table 5 reports OLS estimation results of the demand functions for residential users (columns [1]-[4]) and industrial users (columns [5]-[8]). The odd-numbered columns show estimates for linear quantity-price model (equation [2]), while even-numbered columns are for models with quadratic price terms (equation [3]). Conditional on city and year fixed effects, both residential and industrial water demands are strongly correlated with city population (columns [1], [2], [5], and [6]). However, this correlation is largely weakened and turns statistically insignificant when we include provincial time trends to replace the year fixed effect (columns [3], [4], [7], and [9]). Cities with a higher share of GDP

16 The reflection problem described by Manski (1993) may arise if the peer cities' characteristics, observed or unobserved, that affect the water tariff levels are correlated with the own city's water tariffs and hence water demand. Controlling provincial time trends may help address the issue since peer cities are defined within each province. 
derived from agriculture or industry tend to have less water consumed by the households even when water tariff is controlled. One possible explanation is that households in those cities are more likely to have access to water sources and facilities such as groundwater and wells other than that supplied by water utilities. To a lesser extent, the share of GDP from agriculture is also reversely correlated with industrial water use, but industrial GDP share has a positive, though statistically insignificant, effect. In line with the literature, we find that the residential water consumption decreases with rainfall volume with an elasticity of around $6 \%-8 \%$. Minimum temperature tends to decrease domestic demand and the maximum temperature increases industrial water demand, but the coefficient estimates are significant at the $10 \%$ level only in the models with year fixed effect. Household income proxied by GDP per capita and urban density have little effect on either domestic or industrial water demands. ${ }^{17}$

The estimated common time trends suggest that the industrial water consumption has declined by an average of $9 \%$ per annum across the country between 2000 and 2007. Given that industrial outputs increase steadily in the same period and the industrial share of GDP is controlled in the regressions, the decreasing tread is likely to be attributed to the improved water use efficiency (i.e., decrease in water consumption per unit of industrial output) as well as a structural shift toward less water-intensive production in the industrial sector.

None of the coefficients for tariff variables are precisely estimated. Leaving this issue aside, the estimation of the year fixed effect models yield positive coefficient estimates for the linear term of water tariff, and negative for the quadratic term for both domestic and industrial demands. They imply positive price elasticity at the sample mean or median as shown in the bottom of Table 5 , which are counterintuitive. When the provincial time trends are controlled instead, the coefficient estimates turn negative for the linear tariff variable. The price elasticities derived with these estimates, although lacking statistical precision, is around $7 \%-8 \%$, which falls at the lower end of the range found in the literature. However, these OLS point estimates could still be biased even with control for provincial time trends. One possible source of bias is that the water tariffs are deemed as an effective policy tool to manage water demand and are thus set in anticipation of potential water demand. The reverse causality could lead to underestimation of the price elasticity. Table 6 presents the results from the IV estimation intended to address such endogeneity concerns. ${ }^{18}$

17 We use the average wage of urban employees as an alternative measure of city income level and obtain similar results.

18 The coefficients for other city characteristics in the IV models are largely the same as the OLS estimates, so we focus on tariff-related estimates in Table 6. Full model estimation is available upon request. 
Table 5: Water Demand Regressions-Ordinary Least Squares Estimation

\begin{tabular}{|c|c|c|c|c|c|c|c|c|}
\hline Variables & (1) & $(2)$ & (3) & (4) & (5) & (6) & $(7)$ & $(8)$ \\
\hline Log (urban population) & $\begin{array}{r}0.145^{* *} \\
(0.0679)\end{array}$ & $\begin{array}{r}0.148^{* *} \\
(0.0694)\end{array}$ & $\begin{array}{r}0.0573 \\
(0.0828)\end{array}$ & $\begin{array}{r}0.0557 \\
(0.0837)\end{array}$ & $\begin{array}{c}0.419^{* * *} \\
(0.138)\end{array}$ & $\begin{array}{r}0.420^{* * *} \\
(0.139)\end{array}$ & $\begin{array}{l}0.0377 \\
(0.152)\end{array}$ & $\begin{array}{l}0.0376 \\
(0.152)\end{array}$ \\
\hline GDP agriculture share & $\begin{array}{l}-0.0123^{* * *} \\
(0.00430)\end{array}$ & $\begin{array}{l}-0.0123^{* * *} \\
(0.00430)\end{array}$ & $\begin{array}{r}-0.00843^{* *} \\
(0.00359)\end{array}$ & $\begin{array}{r}-0.00836^{* *} \\
(0.00361)\end{array}$ & $\begin{array}{r}-0.0212^{*} \\
(0.0119)\end{array}$ & $\begin{array}{l}-0.0211^{*} \\
(0.0118)\end{array}$ & $\begin{array}{r}-0.00591 \\
(0.00900)\end{array}$ & $\begin{array}{l}-0.00592 \\
(0.00910)\end{array}$ \\
\hline GDP industry share & $\begin{array}{r}-0.00698^{* * *} \\
(0.00204)\end{array}$ & $\begin{array}{r}-0.00694^{* * *} \\
(0.00203)\end{array}$ & $\begin{array}{r}-0.00685^{* * *} \\
(0.00211)\end{array}$ & $\begin{array}{r}-0.00688^{* * *} \\
(0.00211)\end{array}$ & $\begin{array}{r}0.00471 \\
(0.00508)\end{array}$ & $\begin{array}{r}0.00476 \\
(0.00500)\end{array}$ & $\begin{array}{r}0.00543 \\
(0.00410)\end{array}$ & $\begin{array}{r}0.00544 \\
(0.00406)\end{array}$ \\
\hline Log (rainfall) & $\begin{array}{r}-0.0828^{* *} \\
(0.0354)\end{array}$ & $\begin{array}{r}-0.0822^{* *} \\
(0.0356)\end{array}$ & $\begin{array}{l}-0.0653^{*} \\
(0.0358)\end{array}$ & $\begin{array}{l}-0.0652^{*} \\
(0.0357)\end{array}$ & $\begin{array}{r}-0.0181 \\
(0.0567)\end{array}$ & $\begin{array}{r}-0.0178 \\
(0.0570)\end{array}$ & $\begin{array}{r}0.00767 \\
(0.0452)\end{array}$ & $\begin{array}{r}0.00762 \\
(0.0452)\end{array}$ \\
\hline Maximum temperature & $\begin{array}{r}0.00408 \\
(0.00621)\end{array}$ & $\begin{array}{r}0.00404 \\
(0.00623)\end{array}$ & $\begin{array}{r}0.00323 \\
(0.00537)\end{array}$ & $\begin{array}{r}0.00328 \\
(0.00539)\end{array}$ & $\begin{array}{r}0.0158^{*} \\
(0.00891)\end{array}$ & $\begin{array}{r}0.0156^{*} \\
(0.00880)\end{array}$ & $\begin{array}{r}0.00729 \\
(0.00667)\end{array}$ & $\begin{array}{r}0.00727 \\
(0.00671)\end{array}$ \\
\hline Minimum temperature & $\begin{array}{r}-0.00738^{*} \\
(0.00417)\end{array}$ & $\begin{array}{r}-0.00724^{*} \\
(0.00421)\end{array}$ & $\begin{array}{r}0.00260 \\
(0.00428)\end{array}$ & $\begin{array}{r}0.00268 \\
(0.00425)\end{array}$ & $\begin{array}{l}-0.00649 \\
(0.00719)\end{array}$ & $\begin{array}{r}-0.00631 \\
(0.00710)\end{array}$ & $\begin{array}{r}0.00637 \\
(0.00571)\end{array}$ & $\begin{array}{r}0.00636 \\
(0.00573)\end{array}$ \\
\hline Log (real urban GDP per capita) & $\begin{array}{r}-0.00643 \\
(0.0665)\end{array}$ & $\begin{array}{r}-0.00584 \\
(0.0671)\end{array}$ & $\begin{array}{r}0.0108 \\
(0.0695)\end{array}$ & $\begin{array}{r}0.0113 \\
(0.0694)\end{array}$ & $\begin{array}{r}0.0174 \\
(0.0875)\end{array}$ & $\begin{array}{r}0.0181 \\
(0.0883)\end{array}$ & $\begin{array}{r}0.0312 \\
(0.0861)\end{array}$ & $\begin{array}{r}0.0312 \\
(0.0861)\end{array}$ \\
\hline Log (urban population density) & $\begin{array}{r}0.0214 \\
(0.0321)\end{array}$ & $\begin{array}{r}0.0218 \\
(0.0319)\end{array}$ & $\begin{array}{r}0.0396 \\
(0.0351)\end{array}$ & $\begin{array}{r}0.0402 \\
(0.0349)\end{array}$ & $\begin{array}{r}0.0251 \\
(0.0739)\end{array}$ & $\begin{array}{r}0.0258 \\
(0.0737)\end{array}$ & $\begin{array}{l}-0.0296 \\
(0.0882)\end{array}$ & $\begin{array}{r}-0.0297 \\
(0.0882)\end{array}$ \\
\hline Time trend & & & $\begin{array}{l}-0.0282 \\
(0.0179)\end{array}$ & $\begin{array}{l}-0.0273 \\
(0.0182)\end{array}$ & & & $\begin{array}{r}-0.0900^{* * *} \\
(0.0251)\end{array}$ & $\begin{array}{r}-0.0901^{* * *} \\
(0.0257)\end{array}$ \\
\hline Log (real tariff) & $\begin{array}{r}0.0188 \\
(0.0555)\end{array}$ & $\begin{array}{r}0.0323 \\
(0.0703)\end{array}$ & $\begin{array}{l}-0.0704 \\
(0.0498)\end{array}$ & $\begin{array}{l}-0.0877 \\
(0.0625)\end{array}$ & $\begin{array}{l}0.0708 \\
(0.102)\end{array}$ & $\begin{array}{l}0.0962 \\
(0.221)\end{array}$ & $\begin{array}{l}-0.0855 \\
(0.0764)\end{array}$ & $\begin{array}{r}-0.0800 \\
(0.191)\end{array}$ \\
\hline Log (real tariff)-squared & & $\begin{array}{r}-0.0314 \\
(0.0907)\end{array}$ & & $\begin{array}{r}0.0436 \\
(0.0873)\end{array}$ & & $\begin{array}{r}-0.0254 \\
(0.157)\end{array}$ & & $\begin{array}{r}-0.00570 \\
(0.152)\end{array}$ \\
\hline $\begin{array}{l}\text { Observations } \\
\text { Adj. R-squared }\end{array}$ & $\begin{array}{r}1,178 \\
0.968\end{array}$ & $\begin{array}{r}1,178 \\
0.968\end{array}$ & $\begin{array}{r}1,178 \\
0.968\end{array}$ & $\begin{array}{r}1,178 \\
0.968\end{array}$ & $\begin{array}{r}1,126 \\
0.964\end{array}$ & $\begin{array}{r}1,126 \\
0.964\end{array}$ & $\begin{array}{r}1,126 \\
0.967\end{array}$ & $\begin{array}{l}1,126 \\
0.967\end{array}$ \\
\hline Controls & & & & & & & & \\
\hline $\begin{array}{l}\text { City dummy } \\
\text { Year dummy } \\
\text { Province } \mathrm{x} \text { time trend }\end{array}$ & $\begin{array}{l}Y \\
Y \\
N\end{array}$ & $\begin{array}{l}Y \\
Y \\
N\end{array}$ & $\begin{array}{l}Y \\
N \\
Y\end{array}$ & $\begin{array}{l}Y \\
N \\
Y\end{array}$ & $\begin{array}{l}Y \\
Y \\
N\end{array}$ & $\begin{array}{l}Y \\
Y \\
N\end{array}$ & $\begin{array}{l}Y \\
N \\
Y\end{array}$ & $\begin{array}{l}\mathrm{Y} \\
\mathrm{N} \\
\mathrm{Y}\end{array}$ \\
\hline Calculated elasticities & & & & & & & & \\
\hline $\begin{array}{l}\text { Mean } \\
\text { Median }\end{array}$ & $\begin{array}{l}0.0188 \\
0.0188\end{array}$ & $\begin{array}{l}0.0217 \\
0.0232\end{array}$ & $\begin{array}{l}-0.0704 \\
-0.0704\end{array}$ & $\begin{array}{l}-0.0730 \\
-0.0752\end{array}$ & $\begin{array}{l}0.0708 \\
0.0708\end{array}$ & $\begin{array}{l}0.0758 \\
0.0786\end{array}$ & $\begin{array}{l}-0.0855 \\
-0.0855\end{array}$ & $\begin{array}{l}-0.0846 \\
-0.0839\end{array}$ \\
\hline
\end{tabular}

$\mathrm{GDP}=$ gross domestic product, $\mathrm{N}=$ no, $\mathrm{Y}=$ yes.

Notes: The dependent variable is log (water sold). Columns (1)-(4) estimate demand for residential water and (5)-(8) for industrial water. Standard errors in parentheses are clustered at the city level. $\quad{ }^{* * *} p<0.01,{ }^{* *} p<0.05$, and ${ }^{*} p<0.1$.

Source: Authors' calculations. 
The upper panel of Table 6 shows that the IVs generally have strong explanatory power for the endogenous water tariff variables, echoing the findings from the previous section. For residential demand functions with linear tariff term (columns [1] and [3]), a 10\% increase in the average tariff of the peer cities leads to a $4.5 \%$ or more increase in the city's own tariff. The elasticity decreases to about 0.25 for the industrial sector but remains statistically significant (columns [5] and [7]). The squares of own tariffs are also strongly correlated with the corresponding squares of peer cities' tariffs (columns [2], [4], [6], and [8]). Meanwhile, we note that the weak IV tests suggest that there may be a weak IV problem for the industrial demand regressions (F-stat $<10$ ), except for the specification with quadratic tariffs and year fixed effects.

The lower panel provides the two-stage least squares estimates for the water tariff variables. For residential water demand, the estimated coefficients are negative for the linear term and positive for the quadratic term, which are opposite to the OLS estimates obtained with year fixed effects. The IV estimates with provincial time trend controlled are substantially larger in magnitude than the IV estimates with year fixed effects, as well as the OLS estimates with provincial time trends, and they are statistically significant. The constant elasticity specification suggests a price elasticity of water demand at the city level equal to -0.41 . With variable elasticity specification, the IV-estimated price elasticity is -0.68 for the sample mean and -0.73 for the sample median. These estimates are statistically significant at the $1 \%$ level and fall in the higher spectrum of estimates in the literature.

We see similar patterns in the results for industrial water demand. For models with year fixed effects, we observe negative price elasticities when constant elasticity constraint is dropped. The models with provincial time trends produce negative elasticity estimates for both constant elasticity and variable elasticity specifications. The point estimate is -0.41 in the case of constant elasticity, and -1.26 at the mean and -1.57 at the median in the case of variable elasticity. However, none of them is estimated with statistical precision. ${ }^{19}$

Overall, the results from the IV estimation support the earlier conjecture that decision makers incorporate the anticipated future water demand in setting water tariffs and use the tariffs as a tool to manage water demand. Not addressing this issue, OLS estimation tends to underestimate the price elasticity of water demand.

19 The variable elasticity models yield positive elasticity estimates for certain observations with very large prices. Improving the model specification to deal with this situation is to be further studied. 
Table 6: Water Demand Regressions - Two-Stage Least Squares Estimation

\begin{tabular}{|c|c|c|c|c|c|c|c|c|}
\hline Variables & (1) & (2) & (3) & (4) & (5) & (6) & (7) & (8) \\
\hline \multicolumn{9}{|c|}{ First stage estimation (endogenous variables: log of real tariff and log of real tariff-squared) } \\
\hline \multirow[t]{2}{*}{ Log (neighbor peer tariff) } & $0.450^{* * *}$ & $0.299^{* * *}$ & $0.472^{* * *}$ & $0.350^{* * *}$ & $0.280^{* * *}$ & -0.0803 & $0.246^{* *}$ & -0.0974 \\
\hline & $(0.0986)$ & $(0.112)$ & $(0.101)$ & (0.117) & $(0.0950)$ & $(0.120)$ & $(0.108)$ & $(0.135)$ \\
\hline \multirow[t]{2}{*}{ Log (neighbor peer tariff)-squared } & & $0.259^{* *}$ & & 0.224 & & $0.362^{* * *}$ & & $0.362^{* * *}$ \\
\hline & & $(0.109)$ & & $(0.152)$ & & $(0.0959)$ & & $(0.116)$ \\
\hline First-stage Partial R-squared & 0.0987 & 0.111 & 0.109 & 0.115 & 0.0369 & 0.0733 & 0.0282 & 0.0550 \\
\hline Weak IV F-stat & 20.87 & 15.43 & 21.70 & 13.44 & 8.685 & 12.39 & 5.152 & 7.571 \\
\hline \multirow[t]{2}{*}{ Log (neighbor peer tariff) } & & -0.0651 & & -0.00205 & & $-0.341^{* *}$ & & -0.190 \\
\hline & & $(0.0719)$ & & $(0.0739)$ & & $(0.136)$ & & $(0.158)$ \\
\hline \multirow[t]{2}{*}{ Log (neighbor peer tariff)-squared } & & $0.692^{* * *}$ & & $0.526^{* * *}$ & & $0.712^{* * *}$ & & $0.487^{* * *}$ \\
\hline & & $(0.0745)$ & & $(0.105)$ & & $(0.125)$ & & $(0.140)$ \\
\hline First-stage Partial R-squared & & 0.242 & & 0.147 & & 0.135 & & 0.0591 \\
\hline Weak IV F-stat & & 53.05 & & 15.43 & & 19.51 & & 7.243 \\
\hline \multicolumn{9}{|l|}{ Second stage estimation } \\
\hline \multirow[t]{2}{*}{ Log (real tariff) } & -0.196 & -0.388 & $-0.411^{* * *}$ & $-1.039^{* * *}$ & 0.131 & -0.779 & -0.408 & -3.694 \\
\hline & $(0.159)$ & $(0.391)$ & $(0.130)$ & $(0.345)$ & $(0.348)$ & $(1.013)$ & $(0.390)$ & $(3.821)$ \\
\hline \multirow[t]{2}{*}{ Log (real tariff)-squared } & & 0.254 & & $1.045^{* * *}$ & & 0.693 & & 2.983 \\
\hline & & $(0.360)$ & & $(0.384)$ & & $(0.580)$ & & $(3.120)$ \\
\hline Observations & 1,080 & 1,080 & 1,080 & 1,080 & 1,038 & 1,038 & 1,038 & 1,038 \\
\hline Adj. R-squared & 0.965 & 0.964 & 0.964 & 0.955 & 0.964 & 0.961 & 0.966 & 0.916 \\
\hline \multicolumn{9}{|l|}{ Controls } \\
\hline City dummy & Y & Y & Y & Y & Y & Y & Y & Y \\
\hline Year dummy & Y & Y & $\mathrm{N}$ & $\mathrm{N}$ & Y & Y & $\mathrm{N}$ & $\mathrm{N}$ \\
\hline Province $\mathrm{x}$ time trend & $\mathrm{N}$ & $\mathrm{N}$ & Y & Y & $\mathrm{N}$ & $\mathrm{N}$ & Y & Y \\
\hline \multicolumn{9}{|l|}{ Calculated elasticities } \\
\hline Mean & -0.196 & -0.301 & $-0.411^{* * *}$ & $-0.680^{* * *}$ & 0.131 & -0.215 & -0.408 & -1.264 \\
\hline Median & -0.196 & -0.314 & $-0.411^{* * *}$ & $-0.734^{* * *}$ & 0.131 & -0.285 & -0.408 & -1.566 \\
\hline
\end{tabular}

IV = instrumental variable, $N=$ no, $Y=$ yes.

Notes: The dependent variable is log (water sold). Columns (1)-(4) estimate demand for residential water and (5)-(8) for industrial water. Standard errors in parentheses are clustered at the city level. ${ }^{* * *} p<0.01,{ }^{* *} p<0.05$, and ${ }^{*} p<0.1$.

Source: Authors' calculations. 


\section{WATER SUPPLY ESTIMATION}

In this section, we first estimate the cost function of water supply with utility-level production and real cost data. The water supply or marginal cost function is then derived based on the estimates.

Following Kim (1995), we adopt a translog multiproduct joint cost function to estimate urban water supply. The translog function features a flexible approximation to the production function using second-order Taylor series, adding up level terms, quadratic terms, and cross products of outputs, input prices, and other variables that enter the production function. Given data limitation, we consider two outputs: the annual amount of water supplied to residential and industrial users. The total cost equals the sum of the two outputs multiplied by the utility's unit cost of water supply. Average wage computed from the total wage bill and number of employees is used to measure labor price. We do not observe prices for other inputs such as capital and electricity directly. However, they are less variable across cities or year, so they may be picked up by the fixed effects in the model.

Specifically, we estimate the following model (city and year subscripts are suppressed for simplicity):

$$
\begin{aligned}
& \ln C=a_{0}+\sum_{s} a_{s} \ln q_{s}+b_{w} \ln w+\sum_{k} c_{k} \ln Z_{k}+\frac{1}{2} \sum_{r} \sum_{s} a_{r s} \ln q_{r} \ln q_{s}+b_{w w}(\ln w)^{2}+ \\
& \frac{1}{2} \sum_{j} \sum_{k} c_{j k} \ln Z_{j} \ln Z_{k}+\sum_{s} d_{s w} \ln q_{s} \ln w+\sum_{k} e_{k w} \ln Z_{k} \ln w+\sum_{s} \sum_{k} f_{s k} \ln q_{s} \ln Z_{k}+u
\end{aligned}
$$

where $C$ denotes the total cost, $q_{s}\left(q_{r}\right)$ corresponds to the amount of water supplied to the residential or industrial sector, $w$ denotes wage, and $Z_{k}\left(Z_{j}\right)$ represents a set of control variables including the share of groundwater in total supply capacity, total length of pipes (log), total number of meters (log), and whether the utility has shareholders from the private sector, which may affect the technology or efficiency of water supply. ${ }^{20}$ Consistent with previous water tariff models and water demand models, two specifications for the error term $u$ are considered: first, $u$ is decomposed into a city fixed effect, a year fixed effect and a random error; second, the provincial time trends replace the year fixed effect. Among all the parameters, $a_{r s}=a_{s r}$ and $c_{j k}=c_{k j}$ by the symmetry conditions of the model.

We can derive the cost elasticity of each output by differentiating the fitted Equation (4) with respect to that output:

$$
e_{C q_{s}}=\hat{a}_{s}+\sum_{r} \hat{a}_{s r} \ln q_{r}+\hat{d}_{s w} \ln w+\sum_{k} \hat{f}_{s k} \ln Z_{k}
$$

where $e_{C q_{s}}$ is the cost elasticity of water supply to sector $s$. The marginal cost of water supply to sector $s$, holding the other sector constant, can be obtained as

$$
M C_{s}=\frac{\hat{C}}{q_{s}} e_{C q_{s}},
$$

where $M C_{S}$ is the marginal cost of water supply to sector $s$ and $\hat{C}$ is the fitted total cost.

20 We observe total water supply, total water sold, and water sold to residential and industrial sectors. We calculate the leakage rate with the first two and then apply it to the water sold to each sector to estimate water supplied to the sector. 
Table 7 shows the estimation results of equation (4) with the utility-level panel data from 2001 to 2007. The two specifications, one with year fixed effects and the other with provincial time trends, yield qualitatively similar coefficient estimates. First, the quantity of water supplied to both residential and industrial users are positively correlated with total cost in both linear and quadratic terms, with the quadratic terms statistically significant. Meanwhile, the coefficient of the interaction of residential and industrial quantities is significantly negative, suggesting strong economies of scope gained from the joint production of water supply to residential and industrial sectors.

Wage level has a sizable impact on the water supply cost across specifications. This, to some extent, justifies the public's concern that the high salaries paid to the utility employees, often set without sufficient transparency, drive up the water price. Water supply cost increases with the share of capacity to process water from underground sources (significant at the $10 \%$ level in the provincial time trend model). However, this relation is dampened when the amount of supply, especially supply to the residential sector, is large. Finally, the total length of pipes, especially when the industrial water supply is high, has a large impact on the supply cost.

The bottom panel of Table 7 presents the cost elasticities with respect to residential and industrial water supply computed by equation (5) for the city-year with sample median of the total water supply. The estimates, statistically significant at the $1 \%$ level, indicate that a $10 \%$ increase in residential (industrial) water supply leads to a $5.8 \%$ (2.4\%) increase in the total cost. Urban water supply is a textbook case of natural monopoly. It features significant economies of scale as the production relies on large-scale networks, which require extremely high initial investment, whereas the daily operation of the system is much less expensive. The estimated elasticities clearly demonstrate such scale economies in the urban water systems in the context of the PRC.

Table 7: Water Supply Cost Regression

\begin{tabular}{lcc}
\hline Variables & $(1)$ & $(2)$ \\
\hline Log (residential water supply) & 0.488 & 0.596 \\
& $(0.511)$ & $(0.568)$ \\
Log (industrial water supply) & 0.236 & 0.207 \\
& $(0.284)$ & $(0.326)$ \\
Log (residential water supply)-squared & $0.105^{* *}$ & $0.0878^{*}$ \\
& $(0.0472)$ & $(0.0509)$ \\
Log (residential water supply) ${ }^{*}$ Log (industrial water supply) & $-0.130^{* * *}$ & $-0.134^{* * *}$ \\
& $(0.0491)$ & $(0.0507)$ \\
Log (industrial water supply)-squared & $0.0351^{* *}$ & $0.0379^{* *}$ \\
& $(0.0165)$ & $(0.0157)$ \\
Log (real average wage) & $0.751^{*}$ & $0.858^{* *}$ \\
Share of groundwater to total supply capacity & $(0.419)$ & $(0.427)$ \\
& 2.176 & $2.717^{*}$ \\
Log (pipe length) & $(1.360)$ & $(1.571)$ \\
& -0.132 & -0.327 \\
Log (number of water meters) & $(0.549)$ & $(0.605)$ \\
Private sector participation indicator & 0.173 & 0.119 \\
& $(0.273)$ & $(0.286)$ \\
& 0.0409 & 0.0831 \\
\end{tabular}




\begin{tabular}{|c|c|c|}
\hline Variables & (1) & (2) \\
\hline Log (real average wage)-squared & $\begin{array}{r}0.0688 \\
(0.0629)\end{array}$ & $\begin{array}{r}0.0552 \\
(0.0602)\end{array}$ \\
\hline Log (real average wage) * Share of groundwater to total capacity & $\begin{array}{r}0.182 \\
(0.160)\end{array}$ & $\begin{array}{r}0.120 \\
(0.162)\end{array}$ \\
\hline Log (real average wage) ${ }^{*} \log$ (pipe length) & $\begin{array}{l}0.0412 \\
(0.101)\end{array}$ & $\begin{array}{r}0.0441 \\
(0.100)\end{array}$ \\
\hline Log (real average wage) ${ }^{*} \log$ (number of water meters) & $\begin{array}{r}-0.0237 \\
(0.0411)\end{array}$ & $\begin{array}{r}-0.0110 \\
(0.0397)\end{array}$ \\
\hline Log (real average wage) * Private sector participation indicator & $\begin{array}{l}-0.0946 \\
(0.0719)\end{array}$ & $\begin{array}{r}-0.0682 \\
(0.0704)\end{array}$ \\
\hline Share of groundwater to total capacity-squared & $\begin{array}{r}-0.174 \\
(0.379)\end{array}$ & $\begin{array}{r}-0.139 \\
(0.458)\end{array}$ \\
\hline Share of groundwater to total capacity * Log (pipe length) & $\begin{array}{r}0.274 \\
(0.195)\end{array}$ & $\begin{array}{r}0.251 \\
(0.179)\end{array}$ \\
\hline Share of groundwater to total capacity ${ }^{*} \log$ (number of water meters) & $\begin{array}{r}-0.0714 \\
(0.0820)\end{array}$ & $\begin{array}{r}-0.114 \\
(0.0865)\end{array}$ \\
\hline Share of groundwater to total capacity * PPP dummy & $\begin{array}{r}-0.0583 \\
(0.0873)\end{array}$ & $\begin{array}{r}-0.0141 \\
(0.0905)\end{array}$ \\
\hline Log (pipe length)-squared & $\begin{array}{r}0.143^{*} \\
(0.0829)\end{array}$ & $\begin{array}{r}0.119 \\
(0.0787)\end{array}$ \\
\hline Log (pipe length) ${ }^{*} \log$ (number of water meters) & $\begin{array}{l}-0.0707 \\
(0.0610)\end{array}$ & $\begin{array}{r}-0.0595 \\
(0.0608)\end{array}$ \\
\hline Log (pipe length) * Private sector participation indicator & $\begin{array}{r}0.0483 \\
(0.0750)\end{array}$ & $\begin{array}{r}0.0533 \\
(0.0744)\end{array}$ \\
\hline Log (number of water meters)-squared & $\begin{array}{r}-0.00980 \\
(0.0217)\end{array}$ & $\begin{array}{r}-0.00654 \\
(0.0244)\end{array}$ \\
\hline Log (number of water meters) * Private sector participation indicator & $\begin{array}{r}0.00202 \\
(0.0411)\end{array}$ & $\begin{array}{r}-0.0210 \\
(0.0423)\end{array}$ \\
\hline Log (residential water supply) * Log (real average wage) & $\begin{array}{l}-0.0524 \\
(0.0736)\end{array}$ & $\begin{array}{l}-0.0823 \\
(0.0725)\end{array}$ \\
\hline Log (residential water supply) * Share of groundwater to total capacity & $\begin{array}{r}-0.344^{* *} \\
(0.171)\end{array}$ & $\begin{array}{r}-0.334^{*} \\
(0.189)\end{array}$ \\
\hline Log (residential water supply) ${ }^{*}$ Log (pipe length) & $\begin{array}{r}-0.165 \\
(0.100)\end{array}$ & $\begin{array}{r}-0.136 \\
(0.100)\end{array}$ \\
\hline Log (residential water supply) ${ }^{*} \log$ (number of water meters) & $\begin{array}{r}0.0477 \\
(0.0445)\end{array}$ & $\begin{array}{r}0.0495 \\
(0.0498)\end{array}$ \\
\hline Log (residential water supply) * Private sector participation indicator & $\begin{array}{r}-0.0261 \\
(0.0628)\end{array}$ & $\begin{array}{r}-0.0145 \\
(0.0539)\end{array}$ \\
\hline Log (industrial water supply) ${ }^{*} \log$ (real average wage) & $\begin{array}{r}-0.0488 \\
(0.0609)\end{array}$ & $\begin{array}{r}-0.0467 \\
(0.0633)\end{array}$ \\
\hline Log (industrial water supply) * Share of groundwater to total capacity & $\begin{array}{r}-0.0563 \\
(0.0734)\end{array}$ & $\begin{array}{r}-0.0693 \\
(0.0786)\end{array}$ \\
\hline Log (industrial water supply)* Log (pipe length) & $\begin{array}{l}0.0690^{* *} \\
(0.0333)\end{array}$ & $\begin{array}{l}0.0915^{* *} \\
(0.0383)\end{array}$ \\
\hline Log (industrial water supply) ${ }^{*} \log$ (number of water meters) & $\begin{array}{r}0.0151 \\
(0.0286)\end{array}$ & $\begin{array}{r}0.00518 \\
(0.0303)\end{array}$ \\
\hline Log (industrial water supply) * Private sector participation indicator & $\begin{array}{r}-0.0161 \\
(0.0328)\end{array}$ & $\begin{array}{r}-0.00827 \\
(0.0278)\end{array}$ \\
\hline
\end{tabular}


Table 7 continued

\begin{tabular}{|c|c|c|}
\hline Variables & (1) & (2) \\
\hline Time trend & & $\begin{array}{l}0.0381^{* *} \\
(0.0186)\end{array}$ \\
\hline \multirow[t]{2}{*}{ Constant } & 1.380 & 1.384 \\
\hline & $(2.571)$ & $(2.882)$ \\
\hline Observations & 866 & 866 \\
\hline Adj. R-squared & 0.974 & 0.974 \\
\hline \multicolumn{3}{|l|}{ Controls } \\
\hline City dummy & Y & Y \\
\hline Year dummy & Y & $\mathrm{N}$ \\
\hline Province $x$ time trend & $\mathrm{N}$ & Y \\
\hline \multicolumn{3}{|c|}{ Elasticity at median city (Xuzhou, Jiangsu Province [2006]) } \\
\hline Residential & $0.579^{* * *}$ & $0.586^{* * *}$ \\
\hline Industrial & $0.271^{* * *}$ & $0.278^{* * *}$ \\
\hline
\end{tabular}

Notes: The dependent variables are the total cost of supplying water to residential and industrial users. Standard errors in parentheses are clustered at the city level. ${ }^{* * *} p<0.01,{ }^{* *} p<0.05$, and ${ }^{*} p<0.1$.

Source: Authors' calculations.

We further derive the sectoral marginal cost functions, i.e., equation (6), for each city-year with estimates from column (2) of Table 7 and the estimated residuals. Figure 2 illustrates the marginal cost curves for three cities, whose total water supply equal to $10 \%, 50 \%$, and $90 \%$ of the sample in 2007 , respectively. Despite the differences in shape and placement of these curves, they exhibit common inverted$U$ relationship between the marginal cost and quantity across cities and user sectors. Moreover, the turning points of the curves occur at relatively small amounts of quantity, and a large portion of the right, downward sloping part of the curves go flat. In the charts, all the three cities fall on the downward sloping part of the marginal cost curves. It is further confirmed by a simple numerical exercise we conduct to compute the derivative of the marginal cost with respect to the quantity at the actual quantity supplied. The results show that the majority of our sample city-years-78\% for residential supply and $94 \%$ for industrial supply-are on the right of the turning points and many, especially the larger cities, lie on the flat portion of the curves.

Figure 2: Estimated Marginal Cost Curves
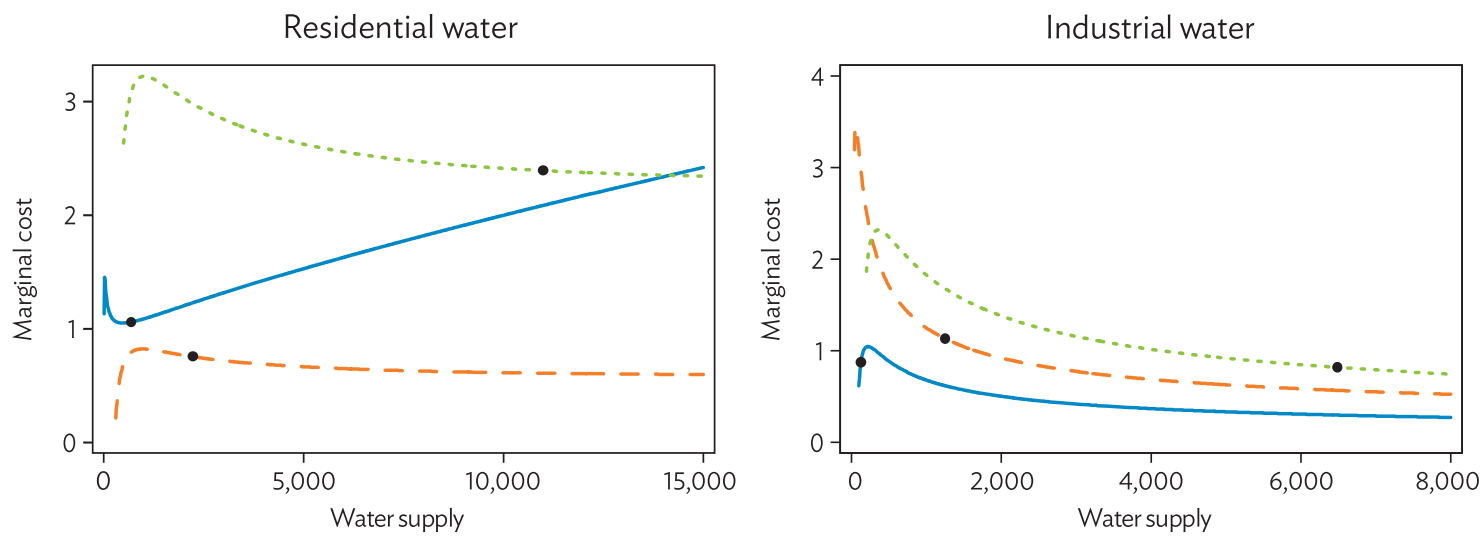

Notes: The sold, dashed, and dotted lines represent marginal cost curves of city-years with 10, 50, and 90 percentiles of water supply in the respective sectors with dots indicating the amounts of actual water supply. In the left chart (residential supply), they are Zhoukou (Henan Province) in 2005, Xuzhou (Jiangsu Province) in 2006, and Changchun (Jilin Province) in 2004, respectively. In the right chart (industrial supply), they are Xianyang (Shaanxi Province) in 2007, Xuzhou (Jiangsu Province) in 2006, and Nanchang (Jianxi Province) in 2003, respectively.

Source: Authors' calculations. 
To the best of our knowledge, our results represent the first systematic evidence on the inverted-U shaped marginal cost of urban water supply from a developing country. However, evidence on downward sloping marginal cost curves is not unique in the literature, as Brown, Caves, and Christensen (1979) show diminishing marginal costs for both passenger and freight services in US railways, and Zekri and Dinar (2003) find a downward sloping supply curve for rural water services in Tunisia. $^{21}$

\section{WELFARE ANALYSIS}

The estimation of demand and marginal cost functions allows us to determine the optimal water tariffs and the extent of deviation from the social welfare maximizing level under first-best pricing. Furthermore, we consider water supply leakages, which averaged around $20 \%$ of total water supply across the country, in setting efficient prices to minimize deadweight loss. For simplicity, we use the constant elasticity estimates of the demand functions (columns [3] and [7] in Table 6). All the pricerelated variables are in real terms.

\section{A. Price-Marginal Cost Gap and Deadweight Loss under First-Best Pricing}

We start with the first-best pricing that suggests that social welfare is maximized when water tariffs are set equal to marginal costs. In this context, it is informative to examine the difference between actual water tariffs and the marginal costs estimated at the amount of water consumed. Panel A of Table 8 reports the tariff-marginal cost gap as a percentage of the tariff for the whole sample, for which we are able to obtain the equilibrium tariffs, as well as the subsamples whose tariffs are higher or lower than the marginal costs. In the case of residential water use, the average margin between tariff and marginal cost is slightly positive at $2.1 \%$, and the median is $5.3 \%$. The distribution of positive and negative margins seems quite symmetric: 385 city-years have tariffs exceeding the estimated marginal costs, while 301 have the reverse. The average gaps are $29.2 \%$ for the former and $-32.5 \%$ for the latter. The absolute values of the medians as well as 10 percentiles and 90 percentiles are also comparable between the two subsamples.

21 Brown, Caves, and Christensen (1979) adopt a multiproduct cost function similar to the one used in this study, while Zekri and Dinar (2003) estimate a log-log supply function. 
Table 8: Tariff-Marginal Cost Gaps and Deadweight Loss under First-Best Pricing

\begin{tabular}{|c|c|c|c|c|c|c|}
\hline & Counts & Mean & Std. Dev. & $10 \%$ & Median & $90 \%$ \\
\hline \multicolumn{7}{|l|}{ (a) Tariff-MC Gap (\% of tariff) } \\
\hline \multicolumn{7}{|l|}{ Residential } \\
\hline All & 686 & 2.1 & 43.1 & -42.9 & 5.3 & 50.6 \\
\hline City-years with tariff $>M C$ & 385 & 29.2 & 21.3 & 4.9 & 23.3 & 60.6 \\
\hline City-years with tariff $<M C$ & 301 & -32.5 & 39.0 & -64.7 & -21.7 & -4.6 \\
\hline \multicolumn{7}{|l|}{ Industrial } \\
\hline All & 662 & 17.7 & 71.4 & -52.8 & 26.3 & 79.4 \\
\hline City-years with tariff $>M C$ & 470 & 48.6 & 35.4 & 10.5 & 43.0 & 89.7 \\
\hline City-years with tariff $<M C$ & 192 & -57.9 & 80.6 & -126.9 & -29.1 & -7.0 \\
\hline \multicolumn{7}{|c|}{ (b) Deadweight Loss (\% of revenue) } \\
\hline \multicolumn{7}{|l|}{ Residential } \\
\hline All & 686 & 3.7 & 7.6 & 0.05 & 1.2 & 10.4 \\
\hline City-years with tariff $>M C$ & 385 & 3.9 & 5.4 & 0.05 & 1.3 & 11.4 \\
\hline City-years with tariff $<M C$ & 301 & 3.6 & 9.7 & 0.05 & 0.9 & 7.1 \\
\hline \multicolumn{7}{|l|}{ Industrial } \\
\hline All & 662 & 6.0 & 9.4 & 0.16 & 2.8 & 14.7 \\
\hline City-years with tariff $>M C$ & 470 & 5.8 & 6.8 & 0.19 & 3.4 & 14.2 \\
\hline City-years with tariff $<M C$ & 192 & 6.6 & 13.8 & 0.06 & 1.3 & 18.2 \\
\hline Total & 662 & 4.4 & 6.2 & 0.27 & 2.5 & 11.0 \\
\hline
\end{tabular}

$M C=$ marginal cost.

Notes: Tariffs and marginal costs are in real 2000 prices. Deadweight loss is calculated at the equilibrium price (i.e., price equal to marginal cost) for each city-year that has valid estimates for demand and cost functions.

Source: Authors' calculations.

For industrial water use, the tariff-marginal cost gaps are more skewed toward positive values with greater variation. The average gap for the whole sample is $17.7 \%$ with median equal to $26.3 \%$, both considerably larger than those of residential water. ${ }^{22}$ Among 662 city-year observations, 470 or $71 \%$ have tariffs higher than the marginal costs with an average of $48.6 \%$. Although observations with higher marginal costs account for less than $30 \%$ of the total, the mean is as large as $-57.9 \%$ and the marginal costs more than double the tariff in several instances (the gap-to-tariff ratio is lower than $-100 \%$ ). ${ }^{23}$

Next, we turn to calculating the deadweight loss due to the gap between water tariff and marginal cost. First, the demand functions, $P^{D}(Q)=f\left(Q ; u_{i t}\right)$, are derived from equation (2) with estimated coefficients from column (4) for the residential sector and column (8) for the industrial sector in Table 6. Marginal cost function, $M C(Q)=g\left(Q ; v_{i t}\right)$, is derived based on the estimates for equation (4) from column (2) of Table 7. Note that $u_{i t}$ and $v_{i t}$ in the two functions denote covariates as well as estimated residuals specific for each city-year.

22 We drop 24 city-years with negative marginal costs at the quantities consumed.

23 For comparison, Kim (1995) studies US water utilities in the early 1970s and finds the margins between average water price and marginal cost as a share of marginal cost, which are $158 \%$ for the residential sector and $40 \%$ for the industrial sector. 
Second, we obtain the equilibrium quantity $Q_{i t}^{e}$ such that $f\left(Q_{i t}^{e} ; u_{i t}\right)=g\left(Q_{i t}^{e} ; v_{i t}\right)$. Finally, the deadweight loss is given by

$$
D W L_{i t}=\left|\int_{Q_{i t}^{e}}^{Q_{i t}^{0}}\left[f\left(Q ; u_{i t}\right)-g\left(Q ; v_{i t}\right)\right] d Q\right|,
$$

where $Q_{i t}^{0}$ is the actual water consumption.

Panel (b) of Table 8 presents the deadweight loss as a share of the water revenue by sector. On average, the deadweight loss resulting from the gap between residential water tariff and marginal cost for residential water consumption equals $3.7 \%$ of the revenue from water sold to residential users, and $6 \%$ for industrial water. The total deadweight loss as a percentage of total revenue is estimated at $4.4 \%$. Examining the distributions suggests that $90 \%$ of city-years have a total deadweight loss equal or lower than $11 \%$ of total revenue, with corresponding shares equal to $10 \%$ for the residential sector and $15 \%$ for the industrial sector. Moreover, more than a quarter of the sample has deadweight loss below $1 \%$. Overall, the results point to moderate deadweight loss under the first-best pricing, and in terms of the share of revenue, the industrial sector incurs greater deadweight loss than the residential sector does.

For the residential sector, the average deadweight loss caused by water priced higher than the marginal cost is slightly larger than that caused by downward pricing (3.9\% versus $3.6 \%$ ), while it is the opposite case for the industrial sector ( $5.8 \%$ versus $6.6 \%$ ). The latter is partly driven by a few extreme cases with large negative gaps between tariffs and marginal costs.

\section{B. Optimal Pricing with Nonrevenue Water}

People may argue that first-best pricing does not maximize social welfare on a few different grounds. First, water is considered a scarce resource in most parts of the PRC. Many cities rely on groundwater sources to ensure adequate water supply. Groundwater is largely nonrenewable and characterized as common property. Therefore, water consumption bears a significant negative externality, which is not captured in the water supply costs (Olmstead 2010). To estimate optimal tariffs, one should obtain the city-specific social costs of water consumption, which is beyond the scope of this paper.

Second, water utilities could incur considerable amount of financial loss under the first-best pricing due to the prominent scale economies characteristics of the industry. To keep the utilities in operation, the government needs to raise taxes, which has its own social cost. Kim (1995) proposes the second-best pricing rule that aims to maximize social welfare subject to the constraint that the utility will break even. Applying this rule, the author estimates a positive margin (referred to as the Ramsey number) between the optimal price and marginal cost.

We consider a third case, which is novel in the literature, in which the amount of nonrevenue water is associated with the water consumed and represents a net loss to the society. ${ }^{24}$ Thus, the total loss function ( $T L$ ) will include the cost of nonrevenue water as

$$
T L=\left|\int_{Q^{e}}^{Q^{*}(P)}[f(Q ; u)-g(Q ; v)] d Q\right|+N\left[Q^{*}(P)\right]
$$

24 Here, we define nonrevenue water as the system leakage into nature, not including those consumed by people who do not pay for it. 
where $N(\cdot)$ is the cost function of nonrevenue water and $Q^{*}$ is the water consumption resulting from water tariff $P$. Policy makers need to choose $P$ to minimize $T L$. Given that $N(\cdot)$ increases with $Q^{*}, P$ should be set higher than the equilibrium price such that $Q^{*}<Q^{e}$. Consequently, the first part on the right-hand side of the equation will turn positive, but $N\left(Q^{*}\right)<N\left(Q^{e}\right)$ and the total loss is minimized.

We illustrate the above intuition with a simple simulation using city-years with median residential and industrial water supply (both are in Xuzhou in 2006). For tractability, we specify

$$
N\left(Q^{*}\right)=Q^{*} \cdot N R R \cdot \bar{C}
$$

where $N R R$ refers to a constant ratio of nonrevenue water to water consumed or leakage rate, and $\bar{C}$ is the average cost for the nonrevenue water. For simplicity, we use the average of marginal costs at the actual quantity and first-best quantity to approximate $\bar{C}{ }^{25}$

Table 9 reports the simulation results for both residential and industrial sectors. The first row of each panel shows the actual water tariff and the amount of consumption and associated deadweight loss and loss due to nonrevenue water. The total loss to the society is estimated at CNY8.14 million from the residential sector and CNY5.51 million from the industrial sector. Under the first-best pricing, the price drops and quantity increases (substantially in this particular case) to the equilibrium levels for both sectors. The deadweight loss is minimized to 0 by definition, but the nonrevenue water loss is larger than that in the actual scenario. The total loss is lowered significantly to CNY2.63 million for the residential sector and CNY2.22 million for the industrial sector in this scenario.

Table 9: Illustration of Welfare Computations with Nonrevenue Water Considered

\begin{tabular}{|c|c|c|c|c|c|}
\hline Scenario & Price & Quantity & DWL & $\begin{array}{c}\text { Loss Due to } \\
\text { Nonrevenue } \\
\text { Water }\end{array}$ & Total Loss \\
\hline \multicolumn{6}{|l|}{ Residential } \\
\hline Actual consumption & 2.270 & $1,947.0$ & 651.0 & 163.4 & 814.3 \\
\hline First-best pricing & 0.710 & 3131.1 & 0.0 & 262.7 & 262.7 \\
\hline Nonrevenue water considered & 0.820 & $2,966.7$ & 5.6 & 248.9 & 254.6 \\
\hline \multicolumn{6}{|l|}{ Industrial } \\
\hline Actual consumption & 3.010 & $1,095.0$ & 410.1 & 140.4 & 550.5 \\
\hline First-best pricing & 0.980 & $1,730.0$ & 0.0 & 221.8 & 221.8 \\
\hline Nonrevenue water considered & 1.150 & $1,623.1$ & 6.0 & 208.1 & 214.2 \\
\hline
\end{tabular}

DWL = deadweight loss.

Notes: The illustration is done with demand and cost function estimates for Xuzhou (Jiangsu Province) in 2006, the city-year with median residential and industrial water supply. For tractability, we assume fixed nonrevenue rate at 0.11 . Unit costs of nonrevenue water is assumed to be the average of marginal costs at water sold and water supplied: CNY0.763 per cubic meter $\left(\mathrm{m}^{3}\right)$ for residential water, and CNY1.166 for industrial water. Price is in $\mathrm{CNY} / \mathrm{m}^{3}$, quantity in $10,000 \mathrm{~m}^{3}$, and $\mathrm{DWL}$, nonrevenue loss and total loss all in $10,000 \mathrm{CNY}$.

Source: Authors' calculations.

The third row confirms our intuition about optimal pricing after counting nonrevenue water loss. The price is higher than the equilibrium while the quantity is lower for both sectors. At the

25 The optimization problem may be further developed with the average cost of nonrevenue water that varies with water quantity as well as endogenous leakage rate. We leave this to a separate study. 
expense of a slight increase in the deadweight loss, the nonrevenue water loss is reduced by a larger amount such that the total loss-CNY2.55 million for residential and CNY2.14 million for industrial-is smaller than that under the first-best pricing.

The outcome that the optimal price in the third row is higher than the equilibrium price applies to both situations, wherein the equilibrium price is lower than the actual price (as in the above case) and the equilibrium price is higher than the actual price. In the first situation, the price should be adjusted downward but not as much as the equilibrium price. In the second situation, the price should be adjusted upward exceeding the equilibrium price.

\section{CONCLUSION}

This study develops a framework for analyzing whether water tariffs are set optimally. We start with an effort to understand how urban water tariffs have been set in the context of cities in the PRC in the 2000s. We find that water tariffs have steadily increased in both nominal and real terms in the early 2000s, although the pace of adjustment slowed down after 2007. Among the city-level factors we examined that may affect water tariffs, the single most important one is the average tariff levels of peer cities. This may result from information asymmetry between the government and water utility regarding true water supply costs.

To infer welfare implications of the tariff levels, we estimate the demand and supply functions of water services at the city level to quantify the deadweight loss due to inefficient pricing. To overcome the endogeneity of water tariffs in the demand function, we use peer cities' average tariff as IV for a city's own water tariff. While the OLS estimates suggest that the price elasticity of water demand is nearly 0 and statistically insignificant, the IV approach yields estimates at around -0.41 for both residential and industrial sectors with a constant elasticity specification and even higher estimates with a more flexible specification. On the supply side, we estimate a translog multiproduct joint cost function, from which the marginal cost (supply) function is derived. The results show that the urban water services possess strong scope economies and scale economies. Due to the latter, the majority of our sample city-years falls on the downward sloping segment of the marginal cost curves.

When we overlay the demand and supply functions for each city-year, we find that the cases of actual tariffs higher and lower than marginal costs are equally divided for the residential sector, whereas the incidence of higher actual tariffs accounts for $71 \%$ for the industrial sector. Adopting firstbest pricing rule, the deadweight loss is estimated to be moderate for the majority of the sample. This may be explained by the inelasticity of water demand, relatively small gaps between the actual tariffs and equilibrium tariffs, and the downward slope of the marginal cost curves for many city-years. These results remind us that whether water tariffs are set too low should be assessed on a case-by-case basis with a careful account of the marginal costs of the utility.

We further illustrate that optimal prices should be set higher than the levels under first-best pricing due to the existence of nonrevenue water, which increases with water consumption. In line with externality and utility-break-even arguments, our analysis supports water tariffs set reasonably high to manage water demand, especially in cities suffering from high leakage rate.

Due to data scarcity, our welfare assessment is restricted up to the year 2007. Evidence suggests that the local governments in the PRC did not keep up the pace of adjusting water tariffs after 
2007. For the post-2007 period, our analysis suggests that welfare losses may have increased, and a larger share of the losses could come from the setting of low tariffs.

Besides the novelties in methodology and policy-relevant findings for the PRC, we believe that the framework developed here would be applicable to other countries or regions for which city or community-level water service and tariff data are available. 


\section{REFERENCES}

Allers, Maarten A., and J. Paul Elhorst. 2005. "Tax Mimicking and Yardstick Competition among Local Governments in the Netherlands." International Tax and Public Finance 12 (4): 493-513.

Bell, David R., and Ronald C. Griffin. 2008. "An Annual Quasidifference Approach to Water Price Elasticity.” Water Resources Research 44 (8), W08420: 1-9. doi:10.1029/2007WR006233.

Bell, David R., and Ronald C. Griffin. 2011. "Urban Water Demand with Periodic Error Correction." Land Economics 87 (3): 528-44.

Besley, Timothy, and Anne Case. 1995. "Vote-Seeking, Tax-Setting, and Yardstick Competition." American Economic Review 85 (1): 25-45.

Brown, Randall S., Douglas W. Caves, and Laurits R. Christensen. 1979. "Modelling the Structure of Cost and Production for Multiproduct Firms.” Southern Economic Journal 46 (1): 256-73.

Dalhuisen, Jasper M., Raymond J. G. M. Florax, Henri L. F. de Groot, and Peter Nijkamp. 2003. "Price and Income Elasticities of Residential Water Demand: A Meta-Analysis." Land Economics 79 (2): 292-308.

Davies, Ronald B., and Krishna Chaitanya Vadlamannati. 2013. "A Race to the Bottom in Labor Standards? An Empirical Investigation.” Journal of Development Economics 103: 1-14.

Diakite, Daouda, Aggey Semenov, and Alban Thomas. 2009. "A Proposal for Social Pricing of Water Supply in Cote d'Ivoire." Journal of Development Economics 88 (2): 258-68.

Edmark, Karin, and Hanna Ågren. 2008. "Identifying Strategic Interactions in Swedish Local Income Tax Policies.” Journal of Urban Economics 63 (3): 849-57.

Foster, Henry S., and Bruce R. Beattie. 1981. "On the Specification of Price in Studies of Consumer Demand under Block Price Scheduling." Land Economics 57 (4): 624-29.

Fredriksson, Per G., and Daniel L. Millimet. 2002. "Strategic Interaction and the Determination of Environmental Policy across US States.” Journal of Urban Economics 51 (1): 101-22.

Galiani, Sebastian, Paul Gertler, and Ernesto Schargrodsky. 2005. "Water for Life: The Impact of the Privatization of Water Services on Child Mortality." Journal of Political Economy 113 (1): 83-120.

Ito, Koichiro. 2014. "Do Consumers Respond to Marginal or Average Price? Evidence from Nonlinear Electricity Pricing." American Economic Review 104 (2): 537-63.

Jiang, Yi, and Jingmin Huang, 2015. "Managing Water Resources for Sustainable Growth.” In Managing the Middle-Income Transition: Challenges Facing the People's Republic of China, edited by Juzhong Zhuang, Paul Vandenberg, and Yiping Huang, 539-61. Edward Elgar.

Jiang, Yi, and Xiaoting Zheng. 2014. "Private Sector Participation and Performance of Urban Water Utilities in China." Economic Development and Cultural Change 63 (1): 155-89. 
Kim, H. Youn. 1995. "Marginal Cost and Second-Best Pricing for Water Services." Review of Industrial Organization 10 (3): 323-38.

Lyytikäinen, Teemu. 2012. "Tax Competition among Local Governments: Evidence from a Property Tax Reform in Finland.” Journal of Public Economics 96 (7-8): 584-95.

Manski, Charles F. 1993. "Identification of Endogenous Social Effects: The Reflection Problem." The Review of Economic Studies 60 (3): 531-42.

National Bureau of Statistics. Various years. "Statistical Yearbook of China." Beijing, People’s Republic of China.

Nauges, Celine, and D. Whittington. 2009. "Estimation of Water Demand in Developing Countries: An Overview." The World Bank Research Observer 25 (2): 263-94.

Olmstead, Sheila, 2010. "The Economics of Managing Scarce Water Resources." Review of Environmental Economics and Policy 4 (2): 179-98.

Olmstead, Sheila, W. Michael Hanemann, and Robert N. Stavins. 2007. "Water Demand under Alternative Price Structures." Journal of Environmental Economics and Management 54 (2): 181-98.

Renzetti, Steven. 1999. "Municipal Water Supply and Sewage Treatment: Costs, Prices, and Distortions." Canadian Journal of Economics 32 (3): 688-704.

Shi, Xiangyu, and Tianyang Xi. 2018. "Race to Safety: Political Competition, Neighborhood Effects, and Coal Mine Deaths in China." Journal of Development Economics 131: 79-95.

Timmins, Christopher. 2002. "Measuring the Dynamic Efficiency Costs of Regulators' Preferences: Municipal Water Utilities in the Arid West." Econometrica 70 (2): 603-29.

Wichman, Casey J. 2014. "Perceived Price in Residential Water Demand: Evidence from a Natural Experiment." Journal of Economic Behavior \& Organization 107: 308-23.

Worthington, Andrew C., and Mark Hoffman. 2008. "An Empirical Survey of Residential Water Demand Modelling." Journal of Economic Surveys 22 (5): 842-71.

Yu, Jihai, Li-An Zhou, and Guozhong Zhu. 2016. "Strategic Interaction in Political Competition: Evidence from Spatial Effects across Chinese Cities.” Regional Science and Urban Economics 57: 23-37.

Zekri, Slim, and Ariel Dinar. 2003. "Welfare Consequences of Water Supply Alternatives in Rural Tunisia.” Agricultural Economics 28 (1): 1-12.

Zhang, Bing., K. H. Fang, and Ken Baerenklau. 2017. "Have Chinese Water Pricing Reforms Reduced Urban Residential Water Demand?” Water Resources Research 53 (6): 5057-69.

Zhong, Li-Jin, and Arthur P. J. Mol. 2008. "Participatory Environmental Governance in China: Public Hearings on Urban Water Tariff Setting." Journal of Environmental Management 88 (4): 899-913.

Zhong, Li-Jin, and Arthur P. J. Mol. 2010. "Water Price Reforms in China: Policy-Making and Implementation." Water Resources Management 24 (2): 377-96. 


\section{Water Tariff Setting and Its Welfare Implications: Evidence from Cities in the People's Republic of China}

This study develops a framework to analyze urban water tariff setting and its welfare implications. It applies the framework to panel data on more than 200 cities in the People's Republic of China in the 2000s. First, the authors show that peer cities' average water tariffs have a significant influence on a city's tariff levels. The former is then used as an instrumental variable to correct the endogeneity bias in estimating water demand functions. Estimation of a translog multiproduct joint cost function reveals strong scale and scope economies in urban water supply. Comparing the equilibrium and actual tariffs, the study estimates a moderate welfare loss under first-best pricing in the context of the People's Republic of China.

\section{About the Asian Development Bank}

ADB is committed to achieving a prosperous, inclusive, resilient, and sustainable Asia and the Pacific, while sustaining its efforts to eradicate extreme poverty. Established in 1966, it is owned by 68 members - 49 from the region. Its main instruments for helping its developing member countries are policy dialogue, loans, equity investments, guarantees, grants, and technical assistance. 